\title{
The Relationship between Household Chaos and Child, Parent, and Family Outcomes: A Systematic Scoping Review
}

Samantha Marsh ( $\sim$ sam.marsh@auckland.ac.nz )

University of Auckland https://orcid.org/0000-0001-8129-0350

Rosie Dobson

The University of Auckland

Ralph Maddison

University of Auckland

Research article

Keywords: household chaos, scoping review, family, child development, adolescence

Posted Date: February 20th, 2020

DOI: https://doi.org/10.21203/rs.2.24075/v1

License: (c) (i) This work is licensed under a Creative Commons Attribution 4.0 International License.

Read Full License

Version of Record: A version of this preprint was published at BMC Public Health on April 22nd, 2020. See the published version at https://doi.org/10.1186/s12889-020-08587-8. 


\section{Abstract}

Background: Household chaos, represented by the level of disorganisation or environmental confusion in the home, has been associated with a range of adverse child and family outcomes. This review aims to (1) identify how household chaos is measured, (2) chart study details of household chaos literature, and

(3) map the existing literature with respect to the relationship between household chaos and child, parent, and family outcomes. We expect that this review will highlight the need to consider the importance of household chaos in child well-being research, particularly in those families where children may be more vulnerable to the adverse effects of household chaos.

Methods: We searched five electronic databases (last updated September $1^{\text {st }} 2018$ ) in addition to Google Scholar, and identified publications via a 3-stage screening process, which was conducted by two researchers. Published studies were included if they investigated the association between household chaos and child, parent, or family outcomes. Research that investigated household chaos as a mediator or moderator, or that investigated how the relationship between household chaos and the outcome of interest was mediated or moderated, were also included.

Results: 112 studies in 111 publications were included. The majority were conducted in the United States $(n=71)$, and used either cross-sectional $(n=60)$ or longitudinal $(n=49)$ study designs. Outcomes of interest were categorised into seven categories: (1) cognitive and academic $(n=16),(2)$ socio-emotional and behavioural ( $n=60),(3)$ communication $(n=6),(4)$ parenting, family, and household functioning $(n=21),(5)$ parent outcomes $(n=6),(6)$ hormone $(n=8)$, and (7) physical health and health behaviours $(n=19)$. There was consistent evidence for significant correlations between household chaos and adverse outcomes across all seven categories in diverse populations with respect to age, disease status, and socioeconomic status (SES).

Conclusion: There is consistent evidence for associations between household chaos and a number of adverse child, parent, and family-level outcomes. Household chaos may also help describe variations in outcomes between low SES and child development.

\section{Introduction}

Household chaos represents the level of disorganisation or environmental confusion in the family home, and is characterised by high levels of background stimulation, lack of family routines, absence of predictability and structure in daily activities, and an overly fast pace of family life $(1,2)$. Importantly, the construct of household chaos has been associated with a diverse range of adverse childhood outcomes, including poorer social-emotional functioning, cognitive development, academic achievement, and behavioural problems(3-9). 
Household chaos has been linked with caregiver education, family income, and, perhaps not surprisingly, the number of people living in the household, whereby a lower level of caregiver education, lower family income, and a greater number of people in the home are associated with greater levels of chaos(10). Despite this, the construct also been demonstrated to be distributed across socioeconomic status (SES) (10), and further, associations between household chaos and adverse child outcomes remain after controlling for $\operatorname{SES}(3,11)$. For example, one study showed that household chaos was associated with reduced cognitive ability and IQ in children, even after controlling for parent education/IQ, the home literacy environment, parental negativity, parental warmth, stressful events, and housing conditions(3). Household chaos may therefore represent a unique risk factor for various adverse childhood outcomes, rather than simply reflecting residual confounding with, for example, SES(10).

In addition to the main effects of household chaos, the construct has also been shown to both mediate and moderate relationships between known child risk factors and adverse outcomes. For example, one study documented that the relationship between household chaos and maternal executive function was moderated by SES, suggesting that the adverse effects of household chaos may be exacerbated in socioeconomically distressed contexts (12). Other studies have also shown that household chaos may mediate relationships between child sleep and bodyweight(13), child behavioural problems and bedtime resistance(14), and poverty and socioemotional adjustment(15).

Given the varied ways in which household chaos is associated with adverse child outcomes, it is not surprising that there appears to be growing interest in the construct. Yet despite this interest, and a seemingly large body of evidence demonstrating links between household chaos and a range of adverse child outcomes, no review has been conducted in this field to date. To this end, the goal of this study was to undertake a review to investigate the relationship between household chaos and child-, parent-, and family-level outcomes.

We decided that the ideal method of synthesising the knowledge base at this time, due to the disparate nature of outcomes assessed, age range and disease status of participants, frequency and duration of follow-up, and study designs used, was a systematic scoping review. The scoping review methodology allowed us to (1) investigate how household chaos is measured, (2) summarise the research on how household chaos is included as a primary risk factor of child, parent, and family outcomes, and (3) map the existing literature, with respect to relationships between household chaos and child, parent, and family outcomes. This enabled us to assess not only how household chaos is measured, which is necessary to ensure findings are generalisable across studies, but also what dimensions have been investigated. It also enabled us to summarise the extant scientific research without focussing on a specific outcome, research design, study population (e.g. disease population), or setting(16), therefore 
allowing us to make recommendations for future systematic reviews and meta-analysis within the field. This review seems timely given that there is also a need to better understand if effects are independent of other known risk factors, or instead reflect an important confounding factor.

\section{Methods}

\section{Identification of Studies}

Published scoping review guidelines directed the conduct of this review(17-21). The protocol for this scoping review was not registered. MEDLINE, PubMed, Embase, PsycINFO, and Child Development \& Adolescent Studies were searched from inception through to 1 June 2017, with updated searches run on 8 November 2017 and 1 September 2018. We also ran a general search of 'household chaos' in Google Scholar and assessed hits from the first 100 pages of results for eligibility. An iterative process was used to develop the search strategy. Words associated with potential child, parent, and family outcomes (e.g. attention, aggression, diet, sleep, literacy, parent-child interactions) were combined with words and concepts associated with household chaos (e.g. household chaos, family disorganisation), and words associated with our sample of interest (e.g. children, adolescents, mothers, fathers, family). These combinations were used to form search strings, which were applied and run in the different databases. Filters were used to limit the search to studies available in English. The reference lists of all included manuscripts were searched for any additional articles not identified in by the electronic search. Full details of the MEDLINE search strategy are provided in Table 1. The grey literature was not searched.

\section{Study Selection}

Publications identified through our search strategy went through three stages of screening. During the first stage, titles were screened to establish their relevance to the research question. If relevance could not be established from the title, the study was included in the next stage of screening. During the second stage, abstracts of the selected titles were reviewed according to our inclusion criteria. During the third step, full text articles of the abstracts selected during the previous stage were retrieved and further assessed for relevance. Two researchers conducted this process and disagreements were settled first by discussion and, if necessary, by consultation with a third researcher.

\section{Inclusion Criteria}

We included any published research that investigated the association between measures of household chaos and child, parent, or family outcomes, including health, cognitive, and psychosocial outcomes, as well as family-level processes. We also included any published research that investigated household chaos as a mediator or moderator and any studies that investigated how the relationship between household chaos and the outcomes of interest were mediated or moderated. 
Due to the scoping nature of this review, we included healthy children and parents, in addition to those with diagnosed medical conditions, developmental delays, and behavioural disorders. No limits were set on study design. We included any study that investigated the effects of the household chaos construct; including studies that used terms such as home chaos, environment chaos (restricted to the home), chaotic homes/households, hurried homes, family chaos, chaotic families, and chaotic living. In addition, given that household disorganisation is a defining feature of household chaos, we also included studies that investigated the effects of family disorganisation and household instability.

While lack of family routines and family meals may represent one dimension of the household chaos construct, alone they are not a proxy measure for household chaos. Recently it was shown that household chaos and family routines may actually represent two distinct constructs and, further, that lack of family routines represents a pathway through which household chaos adversely affects child outcomes(22). For these reasons, studies focusing primarily on routines (and those specifically using the Family Routine Inventory) and/or frequency of family meals only were not included in the review.

\section{Data Extraction and Synthesis}

For each included trial, two authors extracted data using an extraction form designed and pre-tested for the purpose of this review. Final data extraction was completed in October 2018. Information extracted from each eligible study included: author(s), year of publication, manuscript title, name of cohort/study, study location, health status of child and/or parent, diagnosed conditions of child and/or parent, SES details, location details (i.e. rural or urban), study aim, whether household chaos was the primary focus of the study, study design, duration and number of follow-ups, whether the study investigated twins/parentchild dyads/individual child/family, number of children/families included, age range of included participants, ethnicity, how household chaos was measured, whether household chaos was reported in the results, outcomes of interest (specifically related to household chaos), whether household chaos was assessed as a mediator and/or moderator, whether the relationship between household chaos and the outcome was mediated and/or moderated, and study results.

Data were summarised to record the number of studies retrieved by country, year of publication, study type, and any characteristics of the population (e.g. low SES, disease status). Outcomes of interest were categorised into seven broad categories (Table 2): (1) cognitive and academic (2) socio-emotional and behavioural, (3) communication, (4) parenting, family, and household functioning, (5) parent outcomes (6) hormone, and (7) physical health and health behaviours. Studies could be included in multiple 
categories of outcomes if they reported outcomes that fell across different categories. A narrative review is provided for each outcome measure of interest.

\section{Results}

A total of 661 manuscripts were identified from searches of databases, Google Scholar, and reference lists, of which 218 were duplicates, leaving 443 that were screened for eligibility. Of these, 295 were removed at the title and abstract screening stages, leaving 148 for eligibility screening of full-text articles. After removal of 51 articles due to ineligibility, and inclusion of an additional 6 and 8 articles from the two updated searches in November 2017 and September 2018, respectively, 111 manuscripts (representing 112 studies) were considered eligible and included in the review (Figure 1).

Figure 1 illustrates the different steps of the data collection process.

Studies were excluded for a number of reasons: (1) household chaos was included within a composite measure of family functioning or household environment, (2) no child, parent, or family outcomes were reported, (3) only predictors of household chaos were assessed, (4) the construct of household chaos was not adequately measured (i.e. a different construct was measured), (5) household chaos was only included as a covariate in the analysis and not reported in the results, (6) the paper reported simulation data, and (7) the paper was retracted.

A summary of characteristics of the included studies can be found in Table 3. Overall there was generally an even mix of cross-sectional and longitudinal study designs ( $n=57$ vs $n=52)$, in addition to two experimental/laboratory studies and one case-control study. With respect to the longitudinal studies, samples were primarily drawn from large, nationally representative, longitudinal cohorts, which was reflected in the relatively large number of analyses conducted in sample sizes of greater than 1000 participants $(24 / 104 ; 23 \%)$.

There has been an increasing trend in recent years in the number of manuscripts investigating the relationship between household chaos and child/parent/family outcomes (Figure 2), with the majority of publications from research conducted in the USA $(n=74)$ and the UK $(n=21)$ (Figure 3). 
Figure 2: Number of household chaos publications by year

Figure 3: Number of published studies/analyses by country

\section{Methods of household chaos assessment}

Studies varied somewhat in the method of household chaos assessment, although overwhelmingly the most frequently used methods were the long-form version of the Confusion, Hubbub, and Order Scale $(\mathrm{CHAOS})(23)(n=44)$ and the short-form version of CHAOS(24) $(n=42)$. The long-form version consists of 15 questions in a True-False response format, with each item reflecting household characteristics that directly represent a chaotic home environment, while at the same time specifically excluding any items that represent adequacy of the dwelling or quality of furnishings, or imply unsanitary conditions. The questionnaire was developed to be used in families regardless of the child's age, and has been demonstrated to have satisfactory internal consistency, test-rest reliability, and adequate psychometric properties(23). The short-form version of CHAOS consists of six items rated on a five-point scale ( $1=$ definitely untrue, $5=$ definitely true), which has been demonstrated to have acceptable internal consistency(24). Another 10 studies used adapted long- and short-versions of CHAOS, and the remaining 16 studies relied on questionnaires developed specifically for the study and/or direct observation in the home.

\section{Outcomes of Interest}

A summary of study characteristics, including sample size, age of participants, study design, SES status of participants, measure of household chaos, and outcome/s of interest can be found in Table 4. Here we provide a brief narrative review of study findings, with outcomes of interest mapped into seven categories.

\section{Cognitive and Academic}

Sixteen manuscripts were identified that investigated the relationship between household chaos and cognitive/academic outcomes(3, 7, 11, 25-37). The studies covered the spectrum of age groups, from very early childhood to later adolescence, although the majority were conducted in young children (i.e. $\leq 5$ years). Outcomes assessed included executive function, IQ, general cognitive ability, and a range of academic measures, including reading comprehension, academic achievement, study skills, and learning. Overall, household chaos was consistently associated with adverse cognitive and academic outcomes. There was also evidence for an effect of household chaos on outcomes after controlling for SES(3, 31, 
33). However, null findings were reported in 2 of the 16 studies; one study ( $n=203)$ did not find a significant relationship between household chaos and cognitive performance(34), while another study $(n=65)$ failed to demonstrate a significant relationship between household chaos and intelligence, academic achievement, and executive functioning in 6-16 years olds(37).

\section{Socio-emotional and Behavioural}

The majority of studies investigated the relationship between household chaos and socio-emotional and behavioural outcomes $(3,4,6,10,15,25,26,29,30,32-34,38-84)$, although $18 / 59$ of these studies only investigated household chaos as a mediator or moderator in the relationship between a predictor and a socio-emotional/behaviour outcome. Outcomes included responses to challenges, social skills/competence, emotion regulation, risky behaviours, attention, aspirations, aggression, conduct problems, and callous-unemotional traits. Overwhelmingly, household chaos was shown to be associated with adverse outcomes in both younger children and adolescents $(3,4,6,10,26,32-34,39,42-45,50,56$, $58,63-65,68,69,73,81,83,84)$; however, it was not shown to be associated with self-regulation and effortful control(54,84), empathy (65), sexual risk or other violent behaviours in adolescents(45), or occupational aspirations in 7 year olds(48).

\section{Communication}

A total of six manuscripts investigated the link between household chaos and communication, all of which were conducted in the early childhood setting $(6,7,24,26,85,86)$. Outcomes assessed included non-verbal abilities, receptive and expressive language, and phonological awareness. Household chaos was consistently linked with adverse effects on communication outcomes across all six analyses. After controlling for all other measures of household chaos, lack of routines was significantly associated with lower receptive vocabulary scores in 5 year olds(6), and in an analysis that controlled for 13 covariates, including maternal education and poverty, household disorganisation was associated with significant decreases in both receptive and expressive language in 3-year-old children $(n=1145)(86)$. Finally, when investigating the heritability of cognitive abilities as a function of the child's early environment, household chaos, which is classified as a proximal environmental determinant, had stronger effects than distal environmental determinants (e.g. SES) on the heritability of verbal ability(85).

\section{Parenting, and Family and Household Functioning}

Twenty-one studies investigated the effects of household chaos on parenting and family functioning(4, $10,46,76,86-102)$, of which five focused on the role of household chaos as a mediator or moderator. Outcomes assessed included parenting, parent-child interactions, discipline, sibling relationships, parental 
response and reactions to child behaviours, family dysfunction, and food insecurity. Household chaos was associated with increased parent-child conflict, decreased parent-child closeness, decreased supportive parenting, decreased positive parenting, and increased negative parenting(88), in addition to less favourable co-parenting, and less emotional availability at bedtime(99). A chaotic home environment was also shown to be associated with less responsive and less stimulating parenting(89), less effective parental discipline(10), greater non-supportive responses to children's emotions and fewer supportive responses $(76,94)$, and greater paternal hostility $(95)$. Greater chaos in the home was associated with increased odds of household members disturbing the efforts of adolescents to fall asleep, and decreased the odds of adolescents reporting that nothing was keeping them awake or making it difficult to sleep(97). Finally, cumulative family disorganisation, but not cumulative family instability, was indirectly associated with children's representation of family dysfunction in drawings, through parenting behaviours (101).

Food insecure households were more likely to have greater household chaos scores compared with food secure households, even after controlling for education and marital status, with higher chaos homes reporting less planning around mealtimes(91). In another study, high and medium household chaos homes were more likely to experience low or very low food security compared with low chaos homes(96). Further, low chaos predicted greater availability of fruits and vegetables in the home and more family meals, while high chaos was a significant predictor of food insecurity risk and greater availability of salty and fatty snacks(102).

\section{Parent Outcomes}

The relationship between household chaos and parent outcomes, including maternal executive function, parent sleep, parent feeding behaviours and weight status, and maternal depression, were assessed in six studies(12, 102-106), of which two studies included sample sizes of less than 50 participants $(103,105)$, and all of which were conducted in the early childhood setting. Household chaos was associated with poorer maternal executive function $(n=153)$, although the modest effect of household chaos overlapped with the effects of co-varying factors, including SES and verbal ability(12). In parents of children aged 18 months to 5 years $(n=44)$, household chaos was significantly associated with fat intake and high serum cortisol levels; however, the relationship between household chaos and fat intake appeared to be somewhat mediated by cortisol levels, although this relationship was not significant(103). In mothers of children aged 2-5 years $(n=550)$, high chaos was associated with greater engagement in emotional and disinhibited eating, while mothers in low chaos households were more likely to be adventurous eaters(102). 
Household chaos was lower in mothers with trajectories of low-stable levels of depression compared with moderate-increasing levels of depression, but not in those with remitting depression(104). In mothers of infants(105), household chaos was strongly correlated with measures of maternal depression, sleep, wake disturbances, and fatigue. Similarly, mothers and fathers of infants in high chaos homes demonstrated greater variability in sleep duration compared with low chaos families, while parental sleep fragmentation mirrored that of the child in low chaos homes, where fragmented sleep decreased for both the parents and child over the course of the first year(106).

\section{Hormones}

Eight studies investigated the role of household chaos in cortisol and autonomic nervous system activity, inflammatory profiles, and gut biomarkers(61, 107-113), with sample sizes ranging from 32 to 1292 participants. For stress physiology, household chaos in early childhood was associated with (1) a blunted diurnal cortisol slope in middle school(113), (2) cortisol levels in 7 year olds who had lower levels of resting heart rate variability(107), (3) stable morning cortisol levels in 6 year olds(61), and (4) lowered morning cortisol levels in 3-4 year olds(109). In 13-16 year olds(112), household chaos was associated with increased systemic inflammation, interleukin-6 (IL-6) levels, and C-reactive protein levels, although the relationship between chaos and systematic inflammation and IL- 6 levels was moderated by SES. In participants aged 18-66 years, household chaos was not related with hair cortisol levels(111) or gutderived biomarkers associated with appetite and regulation(110).

\section{Physical Health, Health Behaviours and Communication Disorders}

Overall, 19 analyses were conducted that investigated the role of household chaos on health and health behaviours: (1) 9 papers specifically looked at physical health outcomes, disease, and communication disorder outcomes $(13,83,102,109,114-118)$, including glycaemic control, child health, weight status, and stutter, (2) 3 studies investigated diet and dietary behaviours $(102,119,120)$, (3) 6 studies looked at sleep $(14,53,97,106,121,122)$, and (4) 2 studies assessed other outcomes, including TV viewing behaviours in a laboratory setting(123) and mothers' perceptions on children's physical activity(124). For glycaemic control, both maternal and paternal household chaos scores were positively associated with $\mathrm{HbA1c}$ in children and adolescents with type 1 diabetes(114) and in children aged 1-13 years with type 1 diabetes mellitus(116). Chaotic homes were also linked with low cortisol levels (hypocorticolism) in children aged 3-4 years, which in turn predicted overweight in girls, both directly and indirectly through the mediating role of satiety responsiveness, and in boys, indirectly through the mediating role of emotional overeating(109). In infants followed during the first year of life, household chaos was also found to significantly predict weight-for-height $z$-scores, even after controlling for possible confounders(118). 
Chaos was found to be associated with maternal feeding goals(120), with lower household chaos associated with more positive maternal feeding goals, such as promotion of child autonomy around eating. Greater household chaos was also shown to be associated with greater consumption of sugarsweetened beverages in preschoolers(102). Further, chaos was associated with mother-report of general child health, even after controlling for SES, maternal health status, and family structure(115). Similarly for older children, self-report of household chaos in 10-year-olds was associated with worse physical health two years later(83).

With respect to sleep, a more chaotic home environment was associated with mixed effects on sleep outcomes in adolescents, including sleep onset latency and sleep duration $(121,122)$; however, in younger children greater scores for household chaos were significantly associated with higher parent-reported scores for bedtime resistance, sleep anxiety, and total sleep problems(14). One study found that infants from highly chaotic homes demonstrated delays in sleep consolidation patterns and greater fragmentation of sleep; however, they also reported longer and more variable sleep duration compared with infants in low chaos homes(106). The authors suggested that this unexpected difference in sleep duration may have reflected a higher quality of sleep in the low chaos households, where sleep was less fragmented and bedtimes and wake times less variable. Chaos in the home environment was not found to be associated with maternal perceptions about physical activity in children(124), stutter severity in children with stutter(117), TV viewing behaviours (i.e. looking patterns) in a laboratory setting(123), or eating in the absence of hunger in low-income toddlers(119).

\section{Mediation and Moderation Analyses}

Table 5 presents results from studies where mediation and moderation analyses were conducted. Household chaos was consistently found to mediate the relationship between predictors of adverse child outcomes. Importantly, a number of studies demonstrated the mediating role of chaotic homes between SES and outcomes $(15,27,108)$, suggesting that the adverse effects of low SES on child outcomes may, at least in part, be mediated by the effects of household chaos. Further, chaotic environments were also shown to moderate the relationship between several predictors of adverse children and family outcomes, including SES(51), parenting $(25,46,59)$, and parental executive function(41), whereby the effects of these predictors were more pronounced in highly chaotic homes. A number of studies also demonstrated the mediating role of parenting on the relationship between household chaos and adverse child outcomes (Table 6) $(6,77,86,92)$, where adverse parenting behaviours may partially explain the relationship between chaos and child outcomes.

\section{Discussion}


The aim of this scoping review was to provide a general summary of the extant research investigating household chaos in children and their families, with respect to (1) measurement tools used, (2) study details, and (3) outcomes assessed. The review found that research to date predominantly relied on either the short- or long-form version of the CHAOS scale, was conducted in either the U.S or U.K, and utilised primarily cross-sectional or longitudinal study designs. Almost a quarter of the research was undertaken in large, nationally representative samples of over 1000 study participants, and mostly focussed on young, healthy children. Both direct and indirect relationships between household chaos and outcomes were investigated, with the majority of studies assessing the relationship between household chaos and socio-emotional and behavioural outcomes. While an in-depth analysis of findings and assessment of bias was beyond the scope of this review, a preliminary summation of the research showed consistency in the evidence for significant relationships between household chaos and adverse effects across seven categories of outcomes in diverse populations with respect to age, disease status, and SES. To the best of our knowledge, this scoping review is the first review to map the literature within this field.

The review demonstrated that household chaos appears to influence a range of child, parent, and family outcomes. The breadth of these findings are not surprising given the diverse ways household chaos potentially interferes with processes in the home environment known to support healthy child development(125). For example, evidence suggests that parenting behaviours and parent-child interactions are compromised within chaotic home environments $(40,90,126,127)$. Parents in chaotic homes have been shown to be less responsive, less stimulating, more likely to interfere with children's attempts at exploration, less likely to provide scaffolding, and more likely to engage in harsher discipline(2). Not surprisingly, parenting was found to mediate the relationship between household chaos and a number of outcomes, including sibling relationship quality(92), child behaviours(65), receptive and expressive language(86), and children's representation of family dysfunction(101). Yet, it was also shown that even in the presence of positive parenting, such as maternal monitoring, the adverse effects of household chaos remain, suggesting that the negative effects of living in a chaotic home environment may not always be overcome by positive parenting practices(72).

It has also been suggested that the mechanism through which chaos impacts on parents is through increasing levels of stress and distraction, resulting in reduced regulatory functioning of the prefrontal lobe, and thus rendering even parents with normal to high emotional regulation and cognitive control compromised in their ability to parent effectively(128). For example, household chaos has been shown to moderate the relationship between parenting behaviours and child outcomes, whereby chaos exacerbates the effects of negative parenting behaviours and undermines the effects of positive parenting behaviours $(4,25,27,59,74,93,98)$.

Household chaos has also consistently been found to impact on measures of stress physiology in young children, and thus may represent a form of toxic, albeit low-level, stress $(107,129)$. Toxic stress in childhood has been linked with increased risk of negative health outcomes in later life(130), and one potential pathway connecting toxic stress in childhood and adult health is through an altered stress response(131). Exposure to household chaos during the preschool years was shown to be associated 
with a blunted diurnal cortisol slope in middle childhood(113), and further, household chaos was found to partially mediate the relationship between low SES and cortisol levels(108). These findings are concerning as a blunted diurnal cortisol slope, which is considered maladaptive, has been identified as a precursor to a number of diseases and disorders in adulthood(132). As such, household chaos may signify an aspect of toxic stress in childhood that should be considered by public health researchers.

It may also be that household chaos impedes child development directly through effects on attention allocation and information-processing skills(1). In the context of a home environment with high frequency or high levels of distractions and background noise, the child develops adaptive techniques for filtering out stimulation; however, these techniques may not be selective, meaning that stimulation that facilitates development is also inadvertently filtered out(133). Importantly, technological advances in the last 10 years may have created greater opportunities for children to be exposed to background media stimulation. For emphasis, it is possible that newer media devices, such as Smartphones, have increased the level of background media distraction that children are exposed to in the modern home environment. These newer devices not only interfere with child attention processes, but can also reduce responsive parenting behaviours. A recent review found that increased mobile connectivity distracts parents from parent-child interactions, and that distracted parents are more likely to be less responsive and sensitive to the needs of their children(134). Further, a 2018 cross-sectional study in preschool-aged children $(n=385)$ found that greater levels of household chaos were associated with increased total screen use in preschoolers and screen-use behaviours related to disrupted nighttime sleep(135). Future research will need to determine whether screen use mediates the relationship between household chaos and outcomes, or alternatively, whether new media devices contribute to the household chaos construct itself.

We also identified a number of studies demonstrating the mediating role of household chaos between risk factors and adverse child outcomes. Of particular interest was the potential role household chaos plays in explaining, at least in part, the relationship between SES and chid outcomes. For example, household chaos was found to mediate the relationship between low SES and daily cortisol output(108), socioemotional adjustment(15), academic achievement (via the disorganisation pathway rather than the instability pathway)(27), and emotional problems(71), but not conduct problems in children with ADHD(48). More generally, household chaos was also shown to mediate relationships between sleep and bodyweight(13), child sleep and anxiety(53), child behavioural problems and sleep resistance(14), and maternal self-regulation and infant distress to limitations(40).

Finally, household chaos was also shown to moderate the relationship between risk/protective factors and outcomes. For example, children in high chaos homes were shown to be more vulnerable to risk factors, such as hostile parenting(83), and less likely to benefit from positive parenting practices, such as parental control (60). Alternatively, children in lower chaos homes appeared more likely to benefit from protective factors, such as parental monitoring(82). A systematic review of these studies is required to document the evidence supporting the mediating and moderating roles of household chaos between risk/protective factors and child outcomes. 
This review had a number of strengths and limitations. The scoping review methodology allowed us to map a heterogeneous research area, providing an overview of research within a field that has previously escaped comprehensive review(20). It also enabled us to summarise research using a variety of study designs and methodologies, and assess a large number of outcomes across several categories. As a result, this scoping review provides a comprehensive overview of published evidence investigating the construct of household chaos, with no limitations on study design, outcomes of interest, context, or age groups. Further, the review appears timely, given the potential for an increasing level of chaos in the daily lives of families(115), in addition to the increasing number of studies published in the field in recent years.

However, scoping reviews are not without their limitations. While we provided a general narrative overview of findings, more work is required to further analyse and synthesise the findings reported in the included studies. Additionally, we did not conduct an assessment of study quality, in line with scoping review guidelines(16), and therefore it is not possible to comment on the quality of the research reported herein, and further, while we followed recommended guidelines for conducting scoping reviews, we did not undertake the optional consultation process. The considerable heterogeneity across studies, with respect to study designs, methodologies, and outcomes of interest, may also be considered a weakness, as it did not allow in-depth synthesis of the findings, and therefore difficulty in identifying nuances in the research, such as critical windows of exposure. Finally, our reliance on published data only subjected the review to publication bias; however, the decision was made to exclude the grey literature, given the large number of published studies identified by the original search.

Our findings highlighted that the majority of research in the area has been conducted in U.S and U.K populations, and as such, studies from other countries may be needed to better understand how chaotic home environments affect families within different cultural contexts. Research is also needed to assess whether household chaos has been increasing in recent years, and if so, if this increase is across the population or only within specific sub-groups. Drivers of this potential change should also be investigated. For example, widespread social changes may have reduced a family's ability to engage in routines, an important pathway by which household chaos may negatively affect children(6). Families today are more likely to have two parents who work(136), and children who are cared for outside the family home(137). These activities may increase family disorganisation and environmental confusion, through increasing logistical demands, feelings of hurriedness, and increasing perceptions of time scarcity, which in turn may result in decreased engagement in important family routines and rituals(138). Finally, while high levels of household chaos negatively influence children and families, it is unknown whether there is an ideal lower limit of household chaos, below which adverse effects of an 'overly structured household' may occur.

Identifying, targeting, and effectively reducing household chaos may offer a unique course of action for (1) improving child, parent, and family outcomes, (2) tackling social, behavioural, cognitive, and health problems linked with low SES in childhood(108), and (3) increasing the impact of family-based programmes designed to improve child outcomes. Yet we do not believe it is possible to make 
recommendations for practice as our scoping review did not assess the methodological quality of the included research(16). Before recommendations can be made, we suggest the need for systematic reviews that focus on specific outcomes of interest, pathways linking chaos and outcomes, and the mediating and moderating role of household chaos between risk and protective factors and child outcomes. These reviews would allow for an assessment of study quality and would enable recommendations to be made about how findings could inform practice. Studies are also needed to assess whether it is possible to reduce household chaos. To the best of our knowledge, no interventions have been undertaken with the primary aim of targeting household chaos and as such no tools are currently available that have demonstrable effectiveness in reducing chaos in the family home. Further, it remains to be seen whether a reduction in household chaos actually translates into positive outcomes for children, parents, and families.

\section{Conclusions}

Our review identified a diverse body of literature investigating the construct of household chaos. We found that chaotic home environments appear to correlate with a broad spectrum of adverse child, parent, and family outcomes, potentially describe, at least to some extent, the relationship between low SES and adverse outcomes, undermine positive parenting behaviours, and exacerbate negative parenting behaviours. Future research is needed to investigate whether household chaos has been increasing in recent years, what factors may have driven the hypothesised increase in household chaos, whether newer mobile media devices create greater opportunity for the experience of household chaos, and, if so, how to capture this in a new or updated measurement tool. The effects of the construct on outcomes also need to be investigated in other cultural contexts, and programmes developed to not only investigate how household chaos can effectively be reduced, but also assess whether a reduction in household chaos translates into improved outcomes. Before recommendations to inform practice can be made, we propose the undertaking of systematic reviews looking at specific outcomes of interest and the pathways through which household chaos impacts on child, parent, and family outcomes.

\section{Abbreviations}

TV

television

SES

socio-economic status

CHAOS

Confusion, Hubbub, and Order Scale

\section{Declarations}


Ethics approval and consent to participate

Not applicable

Consent for publication

Not applicable

\section{Availability of data and materials}

Not applicable

\section{Competing interests}

The authors declare that they have no competing interests.

\section{Funding}

This research was supported by grants from the Heart Foundation of New Zealand, the New Zealand Lotteries Commission, and the Health Research Council of New Zealand (SM). For the remaining authors none were declared.

\section{Authors' contributions}

SM conceptualised the review, designed the search strategy and data extraction form, extracted the data, summarised and interpreted the data, and drafted the paper. RD extracted the data, provided expert advice on how the data was summarised, and substantively revised the paper. RM substantively revised the paper.

\section{Acknowledgements}

Not applicable.

\section{References}


1. Wachs TD, Evans GW. Chaos in context. 2010.

2. Ackerman BP, Brown ED. Physical and psychosocial turmoil in the home and cognitive development. 2010.

3. Deater-Deckard K, Mullineaux PY, Beekman C, Petrill SA, Schatschneider C, Thompson LA. Conduct problems, IQ, and household chaos: A longitudinal multi-informant study. Journal of Child Psychology and Psychiatry. 2009;50(10):1301-8.

4. Coldwell J, Pike A, Dunn J. Household chaos-links with parenting and child behaviour. Journal of Child Psychology and Psychiatry. 2006;47(11):1116-22.

5. Wachs TD, Chan A. Specificity of environmental action, as seen in environmental correlates of infants' communication performance. Child development. 1986:1464-74.

6. Martin A, Razza RA, Brooks-Gunn J. Specifying the links between household chaos and preschool children's development. Early Child Development and Care. 2012;182(10):1247-63.

7. Johnson AD, Martin A, Brooks-Gunn J, Petrill SA. Order in the house! Associations among household chaos, the home literacy environment, maternal reading ability, and children's early reading. MerrillPalmer quarterly (Wayne State University Press). 2008;54(4):445.

8. Aiello JR, Nicosia G, Thompson DE. Physiological, social, and behavioral consequences of crowding on children and adolescents. Child Development. 1979:195-202.

9. Boles RE, Halbower AC, Daniels S, Gunnarsdottir T, Whitesell N, Johnson SL. Family Chaos and Child Functioning in Relation to Sleep Problems Among Children at Risk for Obesity. Behavioral sleep medicine. 2016:1-15.

10. Dumas JE, Nissley J, Nordstrom A, Smith EP, Prinz RJ, Levine DW. Home chaos: sociodemographic, parenting, interactional, and child correlates. Journal of Clinical Child \& Adolescent Psychology. 2005;34(1):93-104.

11. Hart SA, Petrill SA, Deckard KD, Thompson LA. SES and CHAOS as environmental mediators of cognitive ability: A longitudinal genetic analysis. Intelligence. 2007;35(3):233-42.

12. Deater-Deckard K, Chen N, Wang Z, Bell MA. Socioeconomic risk moderates the link between household chaos and maternal executive function. Journal of Family Psychology. 2012;26(3):391-9.

13. Appelhans BM, Fitzpatrick SL, Li H, Cail V, Waring ME, Schneider KL, et al. The home environment and childhood obesity in low-income households: indirect effects via sleep duration and screen time. BMC Public Health. 2014;14:1160.

14. Boles RE, Halbower AC, Daniels S, Gunnarsdottir T, Whitesell N, Johnson SL. Family chaos and child functioning in relation to sleep problems among children at risk for obesity. Behavioral Sleep Medicine. 2017;15(2):114-28.

15. Evans GW, Gonnella C, Marcynyszyn LA, Gentile L, Salpekar N. The role of chaos in poverty and children's socioemotional adjustment. Psychological science. 2005;16(7):560-5.

16. Joanna Briggs Institute. Joanna Briggs Institute Reviewers' Manual: 2017 edition. Australia2017. 
17. Arksey H, O'Malley L. Scoping studies: towards a methodological framework. International journal of social research methodology. 2005;8(1):19-32.

18. Colquhoun HL, Levac D, O'Brien KK, Straus S, Tricco AC, Perrier L, et al. Scoping reviews: time for clarity in definition, methods, and reporting. Journal of clinical epidemiology. 2014;67(12):1291-4.

19. Levac D, Colquhoun H, O'Brien KK. Scoping studies: advancing the methodology. Implementation Science. 2010;5(1):69.

20. Peters MD, Godfrey CM, Khalil H, McInerney P, Parker D, Soares CB. Guidance for conducting systematic scoping reviews. International journal of evidence-based healthcare. 2015;13(3):141-6.

21. Tricco AC, Lillie E, Zarin W, O'Brien KK, Colquhoun H, Levac D, et al. PRISMA extension for scoping reviews (PRISMA-ScR): checklist and explanation. Annals of internal medicine. 2018;169(7):467-73.

22. Larsen K. Organized Chaos: Daily Routines as a Potential Mechanism Linking Household Chaos and Child Behavior Problems. 2019.

23. Matheny AP, Wachs TD, Ludwig JL, Phillips K. Bringing order out of chaos: Psychometric characteristics of the confusion, hubbub, and order scale. Journal of Applied Developmental Psychology. 1995;16(3):429-44.

24. Petrill SA, Pike A, Price T, Plomin R. Chaos in the home and socioeconomic status are associated with cognitive development in early childhood: Environmental mediators identified in a genetic design. Intelligence. 2004;32(5):445-60.

25. Asbury K, Dunn JF, Plomin R. Birthweight-discordance and differences in early parenting relate to monozygotic twin differences in behaviour problems and academic achievement at age 7. Developmental Science. 2006;9(2):F22-F31.

26. Berry D, Blair C, Willoughby M, Garrett-Peters P, Vernon-Feagans L, Mills-Koonce WR. Household chaos and children's cognitive and socio-emotional development in early childhood: Does childcare play a buffering role? Early Childhood Research Quarterly. 2016;34:115-27.

27. Garrett-Peters PT, Mokrova I, Vernon-Feagans L, Willoughby M, Pan Y. The role of household chaos in understanding relations between early poverty and children's academic achievement. Early Childhood Research Quarterly. 2016;37:16-25.

28. Hanscombe KB, Haworth CM, Davis OS, Jaffee SR, Plomin R. Chaotic homes and school achievement: a twin study. Journal of Child Psychology \& Psychiatry \& Allied Disciplines. 2011;52(11):1212-20.

29. Hur E, Buettner CK, Jeon L. Parental depressive symptoms and children's school-readiness: The indirect effect of household chaos. Journal of Child and Family Studies. 2015;24(11):3462-73.

30. Pike A, lervolino AC, Eley TC, Price TS, Plomin R. Environmental risk and young children's cognitive and behavioral development. International Journal of Behavioral Development. 2006;30(1):55-66.

31. Shamama-tus-Sabah S, Gilani N. Household chaos and its association with maternal education, family system, and children's academic achievement in Pakistani culture. Pakistan Journal of Psychological Research. 2010;25(1):19-30. 
32. Shamama-tus-Sabah S, Gilani N. Household chaos, attention and school problems in primary school children. Journal of Behavioural Sciences. 2011;21(1):68.

33. Shamama-tus-Sabah S, Gilani N, Wachs TD. Relation of home chaos to cognitive performance and behavioral adjustment of Pakistani primary school children. International Journal of Behavioral Development. 2011;35(6):507-16.

34. Shamama-tus-Sabah S, Gillani N. Conduct problems, social skills, study skills, and home chaos in school children: A correlational study. Pakistan Journal of Psychological Research. 2011;26(2):201.

35. Taylor J, Ennis CR, Hart SA, Mikolajewski AJ, Schatschneider C. Home environmental and behavioral risk indices for reading achievement. Learning and Individual Differences. 2017;57:9-21.

36. Taylor J, Hart SA. A chaotic home environment accounts for the association between respect for rules disposition and reading comprehension: A twin study. Learning and Individual Differences. 2014;35:70-7.

37. Yarboi J, Compas BE, Brody GH, White D, Rees Patterson J, Ziara K, et al. Association of socialenvironmental factors with cognitive function in children with sickle cell disease. Child Neuropsychology. 2017;23(3):343-60.

38. Asbury K, Dunn JF, Pike A, Plomin R. Nonshared environmental influences on individual differences in early behavioral development: a monozygotic twin differences study. Child Development. 2003;74(3):933-43.

39. Bobbitt KC, Gershoff ET. Chaotic experiences and low-income children's social-emotional development. Children and Youth Services Review. 2016;70:19-29.

40. Bridgett DJ, Burt NM, Laake LM, Oddi KB. Maternal self-regulation, relationship adjustment, and home chaos: Contributions to infant negative emotionality. Infant Behavior and Development. 2013;36(4):534-47.

41. Brieant A, Holmes CJ, Deater-Deckard K, King-Casas B, Kim-Spoon J. Household chaos as a context for intergenerational transmission of executive functioning. Journal of Adolescence. 2017;58:40-8.

42. Brown DD, Weatherholt TN, Burns BM. Understanding parent reports of children's attention behaviors: Role of children's attention skills, temperament, and home environment. Journal of Early Childhood and Infant Psychology. 2010;6:41-58.

43. Brown ED, Low CM. Chaotic living conditions and sleep problems associated with children's responses to academic challenge. Journal of Family Psychology. 2008;22(6):920.

44. Calam R, Jones S, Sanders MR, Dempsey R, Sadhnani V. Parenting and the emotional and behavioural adjustment of young children in families with a parent with bipolar disorder. Behavioural \& Cognitive Psychotherapy. 2012;40(4):425-37.

45. Chatterjee A, Gillman MW, Wong MD. Chaos, Hubbub, and Order Scale and health risk behaviors in adolescents in Los Angeles. The Journal of pediatrics. 2015;167(6):1415-21.

46. Chen N, Deater-Deckard K, Bell MA. The role of temperament by family environment interactions in child maladjustment. Journal of Abnormal Child Psychology. 2014;42(8):1251-62. 
47. Farbiash T, Berger A, Atzaba-Poria N, Auerbach J. Prediction of Preschool Aggression from DRD4 Risk, Parental ADHD Symptoms, and Home Chaos. Journal of Abnormal Child Psychology. 2014;42(3):489-99.

48. Flouri E, Midouhas E, Ruddy A, Moulton V. The role of socio-economic disadvantage in the development of comorbid emotional and conduct problems in children with ADHD. European Child and Adolescent Psychiatry. 2017:1-10.

49. Flouri E, Tsivrikos D, Akhtar R, Midouhas E. Neighbourhood, school and family determinants of children's aspirations in primary school. Journal of Vocational Behavior. 2015;87:71-9.

50. Fontaine NMG, McCrory EJP, Boivin M, Moffitt TE, Viding E. Predictors and Outcomes of Joint Trajectories of Callous-Unemotional Traits and Conduct Problems in Childhood. Journal of Abnormal Psychology. 2011;120(3):730-42.

51. Fuller-Rowell TE, Evans GW, Paul E, Curtis DS. The role of poverty and chaos in the development of task persistence among adolescents. Journal of Research on Adolescence. 2015;25(4):606-13.

52. Gould KL, Coventry WL, Olson RK, Byrne B. Gene-Environment Interactions in ADHD: The Roles of SES and Chaos. Journal of Abnormal Child Psychology. 2017:1-13.

53. Gregory AM, Eley TC, O'Connor TG, Rijsdijk FV, Plomin R. Family influences on the association between sleep problems and anxiety in a large sample of pre-school aged twins. Personality \& Individual Differences. 2005;39(8):1337-48.

54. Gunzenhauser C, Saalbach H, von Suchodoletz A. Boys have not caught up, family influences still continue: Influences on executive functioning and behavioral self-regulation in elementary students in Germany. PsyCh Journal. 2017;6(3):205-18.

55. Hannigan LJ, McAdams TA, Eley TC. Developmental change in the association between adolescent depressive symptoms and the home environment: results from a longitudinal, genetically informative investigation. Journal of Child Psychology and Psychiatry. 2017.

56. Hardaway CR, Wilson MN, Shaw DS, Dishion TJ. Family functioning and externalizing behaviour among low-income children: Self-regulation as a mediator. Infant and Child Development. 2012;21(1):67-84.

57. Human LJ, Dirks MA, DeLongis A, Chen E. Congruence and incongruence in adolescents' and parents' perceptions of the family: Using response surface analysis to examine links with adolescents' psychological adjustment. Journal of Youth and Adolescence. 2016;45(10):2022-35.

58. Jaffee SR, Hanscombe KB, Haworth CM, Davis OS, Plomin R. Chaotic homes and children's disruptive behavior: a longitudinal cross-lagged twin study. Psychological Science. 2012;23(6):64350.

59. Kahn RE, Deater-Deckard K, King-Casas B, Kim-Spoon J. Intergenerational similarity in callousunemotional traits: Contributions of hostile parenting and household chaos during adolescence. Psychiatry Research. 2016;246:815-20.

60. Kim-Spoon J, Maciejewski D, Lee J, Deater-Deckard K, King-Casas B. Longitudinal associations among family environment, neural cognitive control, and social competence among adolescents. 
Developmental Cognitive Neuroscience. 2017;26:69-76.

61. Laurent HK, Neiderhiser JM, Natsuaki MN, Shaw DS, Fisher PA, Reiss D, et al. Stress system development from age 4.5 to 6: family environment predictors and adjustment implications of HPA activity stability versus change. Developmental Psychobiology. 2014;56(3):340-54.

62. Lemery-Chalfant K, Kao K, Swann G, Goldsmith H. Childhood temperament: Passive geneenvironment correlation, gene-environment interaction, and the hidden importance of the family environment. Development and Psychopathology. 2013;25(1):51-63.

63. Midouhas E, Yogaratnam A, Flouri E, Charman T. Psychopathology trajectories of children with autism spectrum disorder: the role of family poverty and parenting. Journal of the American Academy of Child \& Adolescent Psychiatry. 2013;52(10):1057-65.e1.

64. Miller AL, Song J-H, Sturza J, Lumeng JC, Rosenblum K, Kaciroti N, et al. Child cortisol moderates the association between family routines and emotion regulation in low-income children. Developmental Psychobiology. 2017;59(1):99-110.

65. Mills-Koonce W, Willoughby MT, Garrett-Peters P, Wagner N, Vernon-Feagans L. The interplay among socioeconomic status, household chaos, and parenting in the prediction of child conduct problems and callous-unemotional behaviors. Development and Psychopathology. 2016;28(3):757-71.

66. Oliver BR, Pike A, Plomin R. Nonshared environmental influences on teacher-reported behaviour problems: monozygotic twin differences in perceptions of the classroom. Journal of Child Psychology \& Psychiatry \& Allied Disciplines. 2008;49(6):646-53.

67. Panico L, Becares L, Webb EA. Exploring household dynamics: the reciprocal effects of parent and child characteristics. Longitudinal and Life Course Studies. 2014;5(1):42-55.

68. Raver C, Blair C, Garrett-Peters P. Poverty, household chaos, and interparental aggression predict children's ability to recognize and modulate negative emotions. Development and Psychopathology. 2015;27(3):695-708.

69. Shamama-tus-Sabah S, Gilani N, Kamal A, Batool S. Chaotic home conditions and children's adjustment: Study of gender differences. Pakistan Journal of Psychological Research. 2012;27(2):297-313.

70. Shapero BG, Steinberg L. Emotional reactivity and exposure to household stress in childhood predict psychological problems in adolescence. Journal of Youth \& Adolescence. 2013;42(10):1573-82.

71. Shelleby EC, Votruba-Drzal E, Shaw DS, Dishion TJ, Wilson MN, Gardner F. Income and children's behavioral functioning: a sequential mediation analysis. Journal of Family Psychology. 2014;28(6):936-46.

72. Supplee LH, Unikel EB, Shaw DS. Physical environmental adversity and the protective role of maternal monitoring in relation to early child conduct problems. Journal of Applied Developmental Psychology. 2007;28(2):166-83.

73. Tomalski P, Marczuk K, Pisula E, Malinowska A, Kawa R, Niedźwiecka A. Chaotic home environment is associated with reduced infant processing speed under high task demands. Infant Behavior and Development. 2017. 
74. Towe-Goodman NR, Stifter CA, Coccia MA, Cox MJ. Interparental aggression, attention skills, and early childhood behavior problems. Development and psychopathology. 2011;23(02):563-76.

75. Tucker CJ, Sharp EH, Van Gundy KT, Rebellon CJ. Household chaos, relationships with parents and adolescents' future beliefs. Journal of Family Studies. 2015:1-14.

76. Valiente C, Lemery-Chalfant K, Reiser M. Pathways to Problem Behaviors: Chaotic Homes, Parent and Child Effortful Control, and Parenting. Social Development. 2007;16(2):249-67.

77. Vernon-Feagans L, Garrett-Peters P, Willoughby M. Predictors of Behavioral Regulation in Kindergarten: Household Chaos, Parenting, and Early Executive Functions. Developmental Psychology. 2016;52(3):430-41.

78. Vilsaint CL, Aiyer SM, Wilson MN, Shaw DS, Dishion TJ. The ecology of early childhood risk: a canonical correlation analysis of children's adjustment, family, and community context in a high-risk sample. Journal of Primary Prevention. 2013;34(4):261-77.

79. Wang Z, Deater-Deckard K, Petrill SA, Thompson LA. Externalizing problems, attention regulation, and household chaos: a longitudinal behavioral genetic study. Development \& Psychopathology. 2012;24(3):755-69.

80. Wilkinson PO, Trzaskowski M, Haworth CM, Eley TC. The role of gene-environment correlations and interactions in middle childhood depressive symptoms. Development \& Psychopathology. 2013;25(1):93-104.

81. Fisher JH, Brown JL. A prospective, longitudinal examination of the influence of childhood home and school contexts on psychopathic characteristics in adolescence. Journal of youth and adolescence. 2018:1-19.

82. Lauharatanahirun N, Maciejewski D, Holmes C, Deater-Deckard K, Kim-Spoon J, King-Casas B. Neural correlates of risk processing among adolescents: Influences of parental monitoring and household chaos. Child development. 2018;89(3):784-96.

83. Tucker CJ, Sharp EH, Van Gundy KT, Rebellon C. Household Chaos, Hostile Parenting, and Adolescents' Well-Being Two Years Later. Journal of Child and Family Studies. 2018:1-8.

84. Vrijhof Cl, van der Voort A, van IJzendoorn MH, Euser S. Stressful family environments and children's behavioral control: A multimethod test and replication study with twins. Journal of Family Psychology. 2018;32(1):49.

85. Asbury K, Wachs TD, Plomin R. Environmental moderators of genetic influence on verbal and nonverbal abilities in early childhood. Intelligence. 2005;33(6):643-61.

86. Vernon-Feagans L, Garrett-Peters P, Willoughby M, Mills-Koonce R. Chaos, poverty, and parenting: Predictors of early language development. Early Childhood Research Quarterly. 2012;27(3):339-51.

87. Atzaba-Poria N, Pike A. Correlates of parental differential treatment: parental and contextual factors during middle childhood. Child Development. 2008;79(1):217-32.

88. Barnes J, Gardiner J, Sutcliffe A, Melhuish E. The parenting of preschool children by older mothers in the United Kingdom. European Journal of Developmental Psychology. 2014;11(4):397-419. 
89. Corapci F, Wachs TD. Does parental mood or efficacy mediate the influence of environmental chaos upon parenting behavior? Merrill-Palmer Quarterly. 2002;48(2):182-201.

90. Deater-Deckard K, Wang Z, Chen N, Bell MA. Maternal executive function, harsh parenting, and child conduct problems. Journal of Child Psychology \& Psychiatry. 2012;53(10):1084-91.

91. Fiese BH, Gundersen C, Koester B, Jones B. Family chaos and lack of mealtime planning is associated with food insecurity in low income households. Economics \& Human Biology. 2016;21:147-55.

92. Kretschmer T, Pike A. Young children's sibling relationship quality: distal and proximal correlates. Journal of Child Psychology \& Psychiatry \& Allied Disciplines. 2009;50(5):581-9.

93. Mokrova I, O'Brien M, Calkins S, Keane S. Parental ADHD symptomology and ineffective parenting: The connecting link of home chaos. Parenting: Science and Practice. 2010;10(2):119-35.

94. Nelson JA, O'Brien M, Blankson AN, Calkins SD, Keane SP. Family stress and parental responses to children's negative emotions: tests of the spillover, crossover, and compensatory hypotheses. Journal of Family Psychology. 2009;23(5):671-9.

95. Pike A, Atzaba-Poria N, Kretschmer T. Predictors of parenting: Family-wide and child-specific factors. Parenting: Science and Practice. 2016;16(3):147-63.

96. Pinard CA, Calloway EE, Fricke HE, Yaroch AL. A Cross-Sectional Exploration of Food Security, Depression, and CHAOS in Low-Income Households with Children. Journal of Applied Research on Children: Informing Policy for Children at Risk. 2015;6(2):6.

97. Spilsbury JC, Patel SR, Morris N, Ehayaei A, Intille SS. Household chaos and sleep-disturbing behavior of family members: results of a pilot study of African American early adolescents. Sleep health. 2017;3(2):84-9.

98. Wang Z, Deater-Deckard K, Bell MA. Household chaos moderates the link between maternal attribution bias and parenting. Parenting: Science and Practice. 2013;13(4):233-52.

99. Whitesell CJ, Teti DM, Crosby B, Kim B-R. Household chaos, sociodemographic risk, coparenting, and parent-infant relations during infants' first year. Journal of Family Psychology. 2015;29(2):211.

100. Wirth A, Reinelt T, Gawrilow C, Schwenck C, Freitag CM, Rauch WA. Examining the Relationship Between Children's ADHD Symptomatology and Inadequate Parenting: The Role of Household Chaos. Journal of Attention Disorders. 2017:1087054717692881.

101. Zvara BJ, Mills-Koonce WR, Garrett-Peters P, Wagner NJ, Vernon-Feagans L, Cox M, et al. The mediating role of parenting in the associations between household chaos and children's representations of family dysfunction. Attachment \& Human Development. 2014;16(6):633-55.

102. Martin-Biggers J, Quick V, Zhang M, Jin Y, Byrd-Bredbenner C. Relationships of family conflict, cohesion, and chaos in the home environment on maternal and child food-related behaviours. Maternal \& child nutrition. 2018;14(2):e12540.

103. MacRae LM, Darlington G, Haines J, Ma DW. Examination of associations between chaos in the home environment, serum cortisol level, and dietary fat intake among parents of preschool-age children. Applied Physiology, Nutrition, and Metabolism. 2017(999):1-4. 
104. Madigan S, Wade M, Plamondon A, Jenkins JM. Trajectories of maternal depressive symptoms in the early childhood period and family-wide clustering of risk. Journal of Affective Disorders. 2017;215:49-55.

105. Thomas KA, Spieker S. Sleep, Depression, and Fatigue in Late Postpartum. MCN, American Journal of Maternal Child Nursing. 2016;41(2):104-9.

106. Whitesell CJ, Crosby B, Anders TF, Teti DM. Household chaos and family sleep during infants' first year. Journal of Family Psychology. 2018;32(5):622.

107. Blair C, Berry D, Mills-Koonce R, Granger D, Investigators FLP. Cumulative effects of early poverty on cortisol in young children: moderation by autonomic nervous system activity.

Psychoneuroendocrinology. 2013;38(11):2666-75.

108. Chen E, Cohen S, Miller GE. How low socioeconomic status affects 2-year hormonal trajectories in children. Psychological Science. 2010;21(1):31-7.

109. Lumeng JC, Miller A, Peterson KE, Kaciroti N, Sturza J, Rosenblum K, et al. Diurnal cortisol pattern, eating behaviors and overweight in low-income preschool-aged children. Appetite. 2014;73:65-72.

110. Miller AL, Lumeng CN, Delproposto J, Florek B, Wendorf K, Lumeng JC. Obesity-Related Hormones in Low-Income Preschool-Age Children: Implications for School Readiness. Mind, Brain, and Education. 2013;7(4):246-55.

111. O'Brien KM, Tronick E, Moore CL. Relationship between hair cortisol and perceived chronic stress in a diverse sample. Stress and Health. 2013;29(4):337-44.

112. Schreier HM, Roy LB, Frimer LT, Chen E. Family chaos and adolescent inflammatory profiles: the moderating role of socioeconomic status. Psychosomatic Medicine. 2014;76(6):460-7.

113. Doom JR, Cook SH, Sturza J, Kaciroti N, Gearhardt AN, Vazquez DM, et al. Family conflict, chaos, and negative life events predict cortisol activity in low-income children. Developmental psychobiology. 2018;60(4):364-79.

114. Chae M, Taylor B, Lawrence J, Healey D, Reith D, Gray A, et al. Family CHAOS is associated with glycaemic control in children and adolescents with type 1 diabetes mellitus. Acta diabetologica. 2016;53(1):49-55.

115. Dush CM, Schmeer KK, Taylor M. Chaos as a social determinant of child health: Reciprocal associations? Social Science \& Medicine. 2013;95:69-76.

116. Levin L, Kichler JC, Polfuss M. The relationship between hemoglobin A1C in youth with type 1 diabetes and chaos in the family household. The Diabetes Educator. 2013;39(5):696-704.

117. Kraft SJ, Ambrose $\mathrm{N}$, Chon $\mathrm{H}$, editors. Temperament and environmental contributions to stuttering severity in children: The role of effortful control. Seminars in speech and language; 2014: Thieme Medical Publishers.

118. Khatiwada A, Shoaibi A, Neelon B, Emond J, Benjamin-Neelon S. Household chaos during infancy and infant weight status at 12 months. Pediatric obesity. 2018. 
119. Asta K, Miller AL, Retzloff L, Rosenblum K, Kaciroti NA, Lumeng JC. Eating in the absence of hunger and weight gain in low-income toddlers. Pediatrics. 2016;137(5):1-8.

120. Goulding AN, Lumeng JC, Rosenblum KL, Chen YP, Kaciroti N, Miller AL. Maternal Feeding Goals Described by Low-Income Mothers. Journal of Nutrition Education \& Behavior. 2015;47(4):331-7.e1.

121. Bartel K, Williamson $P$, van Maanen A, Cassoff J, Meijer AM, Oort F, et al. Protective and risk factors associated with adolescent sleep: findings from Australia, Canada, and The Netherlands. Sleep Medicine. 2016;26:97-103.

122. Billows M, Gradisar M, Dohnt H, Johnston A, McCappin S, Hudson J. Family disorganization, sleep hygiene, and adolescent sleep disturbance. Journal of Clinical Child \& Adolescent Psychology. 2009;38(5):745-52.

123. Brown DD, Weatherholt TN, Burns BM. Attention skills and looking to television in children from low income families. Journal of Applied Developmental Psychology. 2010;31(4):330-8.

124. Pesch MH, Wentz EE, Rosenblum KL, Appugliese DP, Miller AL, Lumeng JC. "You've got to settle down!": Mothers' perceptions of physical activity in their young children. BMC Pediatrics. 2015;15:149.

125. Bronfenbrenner U, Morris PA. The bioecological model of human development. Handbook of child psychology. 2006.

126. Deater-Deckard K, Chen N, Wang Z, Bell MA. Socioeconomic risk moderates the link between household chaos and maternal executive function. Journal of Family Psychology. 2012;26(3):391.

127. Evans GW, Wachs TD. Chaos and its influence on children's development. Washington, DC: American Psychological Association. 2010.

128. Crandall A, Deater-Deckard K, Riley AW. Maternal emotion and cognitive control capacities and parenting: A conceptual framework. Developmental review. 2015;36:105-26.

129. Blair C, Raver CC. Poverty, stress, and brain development: New directions for prevention and intervention. Academic pediatrics. 2016;16(3):S30-S6.

130. Shonkoff JP, Garner AS, Siegel BS, Dobbins MI, Earls MF, McGuinn L, et al. The lifelong effects of early childhood adversity and toxic stress. Pediatrics. 2012;129(1):e232-e46.

131. Kuras YI, Assaf N, Thoma MV, Gianferante D, Hanlin L, Chen X, et al. Blunted Diurnal Cortisol Activity in Healthy Adults with Childhood Adversity. Frontiers in human neuroscience. 2017;11:574.

132. Heim C, Newport DJ, Heit S, Graham YP, Wilcox M, Bonsall R, et al. Pituitary-adrenal and autonomic responses to stress in women after sexual and physical abuse in childhood. Jama. 2000;284(5):5927.

133. Evans GW, Kliewer W, Martin J. The role of the physical environment in the health and well-being of children. New directions in health psychology assessment. 1991:127-57.

134. Kildare CA, Middlemiss W. Impact of parents mobile device use on parent-child interaction: A literature review. Computers in Human Behavior. 2017;75:579-93. 
135. Emond JA, Tantum LK, Gilbert-Diamond D, Kim SJ, Lansigan RK, Neelon SB. Household chaos and screen media use among preschool-aged children: a cross-sectional study. BMC public health. 2018;18(1):1210.

136. Fullerton Jr HN. Labor force participation: 75 years of change, 1950-98 and 1998-2025. Monthly Lab Rev. 1999;122:3.

137. Baxter J. Child care participation and maternal employment trends in Australia. Australian Institute of Family Studies; 2013.

138. Neumark-Sztainer D, Hannan PJ, Story M, Croll J, Perry C. Family meal patterns: associations with sociodemographic characteristics and improved dietary intake among adolescents. Journal of the american dietetic association. 2003;103(3):317-22.

\section{Tables}

Table 1: Search strategy utilised for MEDLINE (from inception to September 2018)

\begin{tabular}{|c|c|c|}
\hline Search & Search Term & Combination \\
\hline 1 & $\begin{array}{l}\text { Infant/ or Child/ or Adolescent/ or Mothers/ or Fathers/ or Parents/ or Family/ or child.mp. or infant.mp. or } \\
\text { mother.mp. or father.mp. or parent.mp. or adolescent.mp. or teenager.mp. or children.mp. }\end{array}$ & \\
\hline 2 & $\begin{array}{l}\text { (Family disorganization or Family disorganisation or hurried).mp. or (confusion adj2 hubbub).tw. or household } \\
\text { disorganisation.mp. or household disorganization.mp. or (environmental chaos adj5 family).mp. or (environmental } \\
\text { chaos adj5 home).mp. or (environmental chaos adj5 household).mp. or (environmental chaos adj5 house).mp. or } \\
\text { (chaotic environment adj5 family).mp. or (chaotic environment adj5 home).mp. or (chaotic environment adj5 } \\
\text { household).mp. or (chaotic environment adj5 house).mp. or (chaos adj5 family).mp. or (chaos adj5 home).mp. or (chaos } \\
\text { adj5 household).mp. or (chaos adj5 house).mp. or (chaotic adj5 family).mp. or (chaotic adj5 home).mp. or (chaotic adj5 } \\
\text { household).mp. or (chaotic adj5 house).mp. }\end{array}$ & \\
\hline 3 & $\begin{array}{l}\text { (Child health or Obesity or Overweight or Sleep or Diet or nutrition or "screen use" or Television or "family meals" or } \\
\text { eating or Self-Control or self-regulation or Anxiety or Stress or "effortful control" or Attention or aggression or } \\
\text { Decision Making or Resilience or family functioning or Parenting or Family Conflict or parental attitudes or Parenting } \\
\text { or academic achievement or reading or literacy or mathematics or language or cognition or socio-emotional or social- } \\
\text { emotional).mp. }\end{array}$ & \\
\hline 4 & & $\begin{array}{l}1 \text { and } 2 \text { and } \\
3\end{array}$ \\
\hline 5 & & $\begin{array}{l}\text { Limit } 4 \\
\text { to (english } \\
\text { language } \\
\text { and humans) }\end{array}$ \\
\hline
\end{tabular}

Table 2. Specific Outcomes by Outcome Category 


\begin{tabular}{|c|c|}
\hline Outcome Category & Specific Outcomes Assessed \\
\hline Cognitive and academic & $\begin{array}{l}\text { Academic achievement/performance } \\
\text { Cognitive ability/outcomes/development } \\
\text { Executive function } \\
\text { IQ } \\
\text { Study skills } \\
\text { Reading comprehension } \\
\text { Intellectual functioning }\end{array}$ \\
\hline Socio-emotional and behavioural & 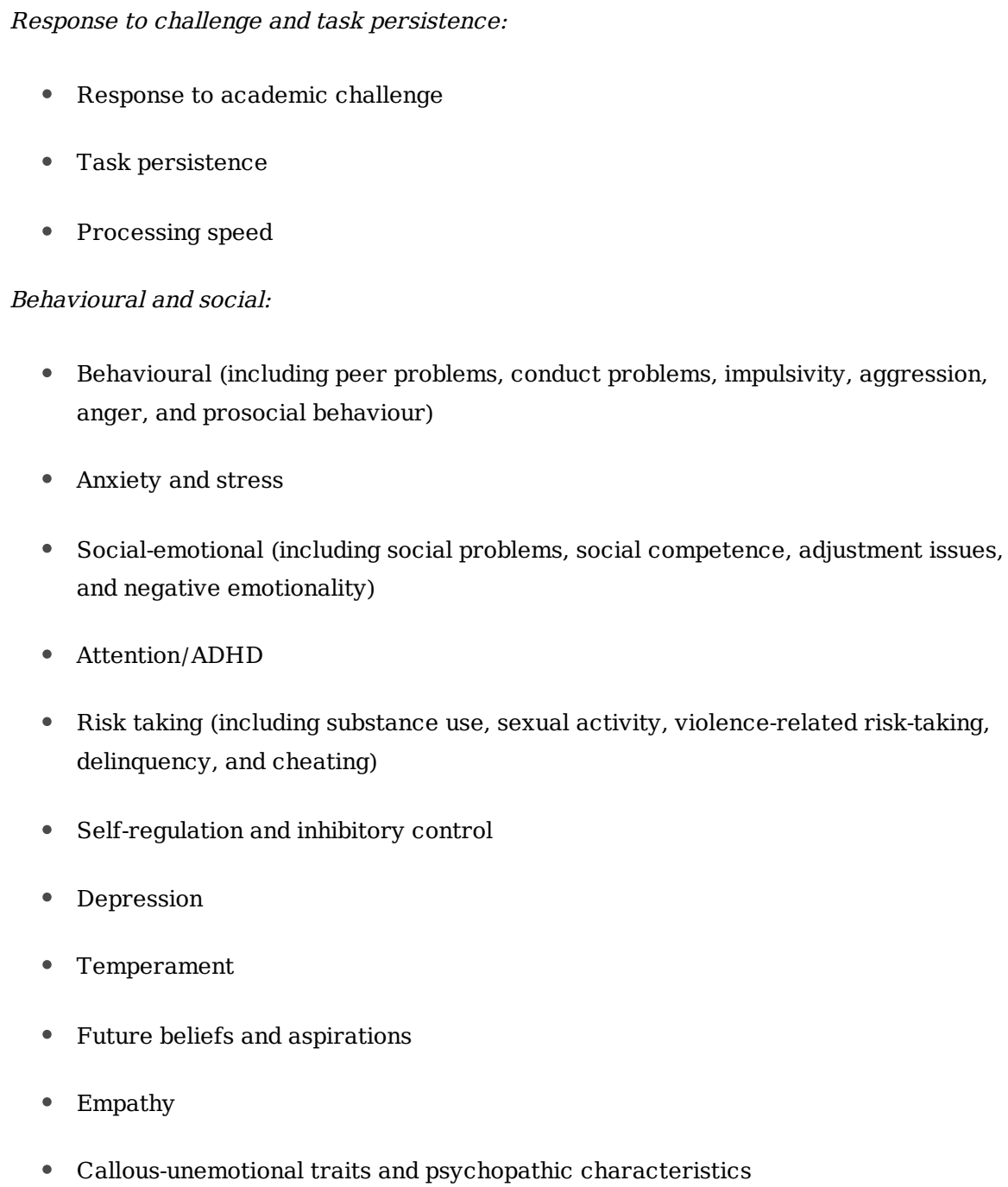 \\
\hline Communication & $\begin{array}{l}\text { Verbal/expressive vocabulary and non-verbal abilities } \\
\text { Receptive vocabulary }\end{array}$ \\
\hline Parenting, family, and household functioning & $\begin{array}{l}\text { Parenting: } \\
\text { - } \text { Differential parenting } \\
\text { - Parent-child closeness } \\
\text { - Parental self-efficacy } \\
\text { - Parental mood } \\
\text { - Harsh parenting } \\
\text { - Discipline }\end{array}$ \\
\hline
\end{tabular}

Page 27/49 
- Sibling relationships

- Sleep-disturbing behaviours of family members

- Parental reactions

- Maternal attribution bias

- Emotional availability

- Child representation of family dysfunction

Household characteristics and food security:

- Food security

- Family meal atmosphere

Parent outcomes

Maternal executive function

Parent diet/eating behaviours/weight status

Maternal depression

Maternal fatigue

Maternal/parent sleep

Hormone

Cortisol levels/profile

Autonomic nervous system activity

Developmental stability of hypothalamic-pituitary-adrenal axis activity

Gut biomarkers

Inflammatory profile

Physical health, health behaviours, and Health/disease/disorder outcomes:

communication disorders

- Child weight/weight status

- $\mathrm{HbA1c}$

- Child health

- Stuttering severity

- Physical health symptoms

Diet and Dietary behaviours:

- Eating in the absence of hunger

- Maternal feeding goals

- Food-related behaviours

Sleep:

- Sleep

- Sleep anxiety

Other health behaviours/outcomes:

- TV viewing behaviours in a laboratory setting

- Maternal perceptions about physical activity 
Table 3. Summary of Characteristics of Included Studies

Page 29/49 


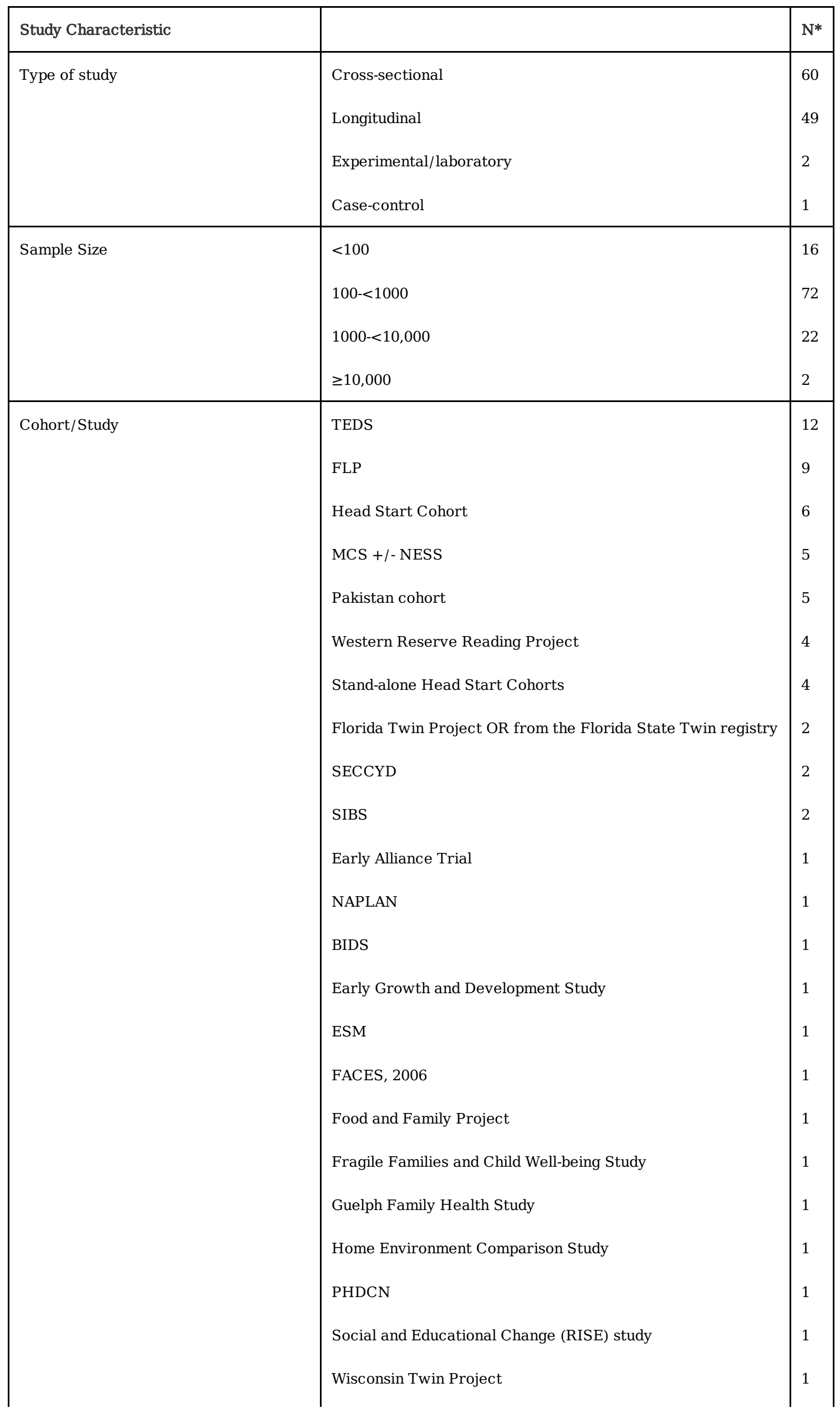

Page 30/49 


\begin{tabular}{|c|c|c|}
\hline & $\begin{array}{l}\text { L-CID } \\
\text { SIESTA } \\
\text { Social and Character Development Research Program } \\
\text { Stand-alone studies/No study or cohort name }\end{array}$ & $\begin{array}{l}1 \\
1 \\
1 \\
46\end{array}$ \\
\hline Context/Participants & $\begin{array}{l}\text { Low income/rural } \\
\text { Twins } \\
\text { Adopted children } \\
\text { Child Diagnosis/Risk factor: } \\
\text { ADHD } \\
\text { Autism } \\
\text { Obesity } \\
\text { DRD4 risk } \\
\text { Stuttering } \\
\text { Sickle cell disease } \\
\text { Type } 1 \text { diabetes } \\
\text { Parent Diagnosis/Risk factor: } \\
\text { Depression/ }\end{array}$ & $\begin{array}{l}3 \\
3 \\
2 \\
4\end{array}$ \\
\hline Measure of Household Chaos Construct & $\begin{array}{l}\text { CHAOS long form } \\
\text { CHAOS short form } \\
\text { CHAOS adapted } \\
\text { Other - questionnaire and/or direct observation }\end{array}$ & 42 \\
\hline
\end{tabular}

TEDS $=$ Twins Early Development Study FLP = Family Life Project; MCS = Millennium Cohort Study; NESS = National Evaluation of Sure Start Impact Study; SECCYD = Study of Early Child Care and Youth Development; SIBS = Sisters and Brothers Study; NAPLAN = Australian Twin Study of the National Assessment Program - Literacy and Numeracy; BIDS = Ben-Gurio University Infant Developmental Study; ESM = Early Steps Multisite project; FACES 2006 = Family and Child Experiences Survey, 2006 cohort; PHDCN = Project on Human Development in Chicago Neighbourhoods; L-CID = Leiden Consortium on Individual Development; SIESTA = Study of Infant's Emergent Sleep TrAjectories; ADHD = Attention-deficit/hyperactivity disorder ; DRD4 = Dopamine Receptor $\mathrm{D}_{4}$

$* \mathrm{~N}=112$ studies reported in 111 manuscripts. 
Studies were included multiple times, for example, if the study was conducted in more than one country, or a manuscript reported results from more than one study. Where data were taken from a longitudinal cohort but analysis was only conducted at one time point, studies were classified as cross-sectional. Where location of study was not reported, location of the first author was used, and where studies investigated participants as parent-child dyads, families, or twin pairs, the unit of participants was used for sample size reporting (e.g. 5000 twin pairs was reported as a sample size of 5000, and 75 parent-child dyads was reported as a sample size of 75).

Table 4: Outcomes of Interest 


\begin{tabular}{|c|c|c|c|c|c|c|c|c|}
\hline \multirow{2}{*}{$\begin{array}{l}\text { OUTCOME OF } \\
\text { INTEREST }\end{array}$} & \multirow[t]{2}{*}{$\mathbf{N}$} & \multirow[t]{2}{*}{ TWIN } & \multirow[t]{2}{*}{$\mathrm{AGE}^{* *}$} & \multicolumn{2}{|c|}{ DESIGN } & \multirow{2}{*}{$\begin{array}{l}\text { LOW } \\
\text { SES }\end{array}$} & \multirow[t]{2}{*}{ Measure of HC } & \multirow[t]{2}{*}{ Outcomes Assessed } \\
\hline & & & & $\mathrm{C} / \mathrm{O}$ & $\mathrm{L}$ & & & \\
\hline
\end{tabular}

\begin{tabular}{|c|c|c|c|c|c|c|c|c|}
\hline Asbury, 2006(25) & 2017 & $\ddot{\mathrm{u}}$ & $0 \mathrm{~m}, 4 \mathrm{y}, 7 \mathrm{y}$ & & $\ddot{\mathrm{u}}$ & & CHAOS short form & $\begin{array}{l}\text { HC as moderator between non-shared } \\
\text { environment variables and academic } \\
\text { achievement }\end{array}$ \\
\hline Berry, 2016(26) & 1235 & & $\begin{array}{c}2 \mathrm{~m}, 7 \mathrm{~m}, 2 \mathrm{y}, 3 \mathrm{y} \\
5 \mathrm{y}\end{array}$ & & $\ddot{\mathrm{u}}$ & $\ddot{\mathrm{u}}$ & $\begin{array}{l}\text { Interview/ } \\
\text { observation }\end{array}$ & $\begin{array}{l}\text { Academic achievement; executive } \\
\text { function }\end{array}$ \\
\hline $\begin{array}{l}\text { Deater-Deckard, } \\
2009(3)\end{array}$ & 302 & $\ddot{\mathrm{u}}$ & $4-7 y$ & $\ddot{\mathrm{u}}$ & $\ddot{\mathrm{u}}$ & & CHAOS short form & IQ \\
\hline $\begin{array}{l}\text { Garrett-Peters, } \\
2016(27)\end{array}$ & 1236 & & $\begin{array}{l}6,15,24,36,48 \\
58 \mathrm{~m} \& \\
\text { kindergarten } \\
\text { (USA) }\end{array}$ & & $\ddot{\mathrm{u}}$ & $\ddot{\mathrm{u}}$ & $\begin{array}{l}\text { Interview/ } \\
\text { observation }\end{array}$ & $\begin{array}{l}\text { HC as mediator between family } \\
\text { income poverty and academic } \\
\text { achievement in kindergarten }\end{array}$ \\
\hline $\begin{array}{l}\text { Hanscombe, } \\
2011(28)\end{array}$ & 2337 & $\ddot{\mathrm{u}}$ & $9 \& 12 y$ & & $\ddot{\mathrm{u}}$ & & CHAOS long form & Academic performance \\
\hline Hart, 2007(11) & 287 & $\ddot{\mathrm{u}}$ & $\begin{array}{l}\text { Kindergarten or } \\
1^{\text {st }} \text { grade, then } \\
1^{\text {st }} \text { or } 2^{\text {nd }} \text { grade } \\
\text { (USA) }\end{array}$ & & $\ddot{\mathrm{u}}$ & & CHAOS short form & $\begin{array}{l}\text { General cognitive ability; HC as } \\
\text { mediator between shared } \\
\text { environmental variance and cognitive } \\
\text { ability }\end{array}$ \\
\hline Hur, 2015(29) & 444 & & $36-70 \mathrm{~m}$ & $\ddot{\mathrm{u}}$ & & & CHAOS short form & $\begin{array}{l}\text { HC as mediator between parent } \\
\text { depressive symptoms and child } \\
\text { cognitive outcomes }\end{array}$ \\
\hline Johnson, 2008(7) & 455 & $\ddot{\mathrm{u}}$ & mean 6.1 years & & & & CHAOS short form & Woodcock score \\
\hline Pike, 2006(30) & 5765 & $\ddot{\mathrm{u}}$ & $0-3 y$, then $4 y$ & & & & CHAOS short form & Cognitive development \\
\hline $\begin{array}{l}\text { Shamama-tus- } \\
\text { Sabah, 2010(31) }\end{array}$ & 203 & & $8-11 y$ & $\ddot{\mathrm{u}}$ & & & CHAOS long form & Academic achievement \\
\hline $\begin{array}{l}\text { Shamama-tus- } \\
\text { Sabah, 2011(32) }\end{array}$ & 101 & & $8-11 y$ & $\ddot{\mathrm{u}}$ & & & CHAOS long form & Learning at school \\
\hline $\begin{array}{l}\text { Shamama-tus- } \\
\text { Sabah, 2011(34) }\end{array}$ & 203 & & $8-11 y$ & $\ddot{\mathrm{u}}$ & & & CHAOS long form & Study skills \\
\hline $\begin{array}{l}\text { Shamama-tus- } \\
\text { Sabah, 2011(33) }\end{array}$ & 203 & & $8-11 y$ & $\ddot{\mathrm{u}}$ & & & CHAOS long form & Cognitive performance \\
\hline Taylor, 2014(36) & & $\ddot{\mathrm{u}}$ & $7-13 y$ & $\ddot{\mathrm{u}}$ & & & CHAOS short form & $\begin{array}{l}\text { HC as mediator between respect for } \\
\text { rules and reading comprehension }\end{array}$ \\
\hline Taylor, 2017(35) & 269 & & $9-16 y$ & $\ddot{\mathrm{u}}$ & & & CHAOS short form & Reading comprehension \\
\hline Yarboi, 2017(37) & 65 & & $6-16 y$ & $\ddot{\mathrm{u}}$ & & & $\begin{array}{l}\text { Interview/ } \\
\text { observation }\end{array}$ & $\begin{array}{l}\text { Intellectual functioning; academic } \\
\text { achievement; executive functioning }\end{array}$ \\
\hline
\end{tabular}

SOCIO-EMOTIONAL \& BEHAVIORUAL $(3,4,6,10,15,25,26,29,30,32-34,38-84)$

Response to Challenge \& Task Persistence

\begin{tabular}{|c|c|c|c|c|c|c|c|c|}
\hline Brown, 2008(43) & 96 & & $3-5 y$ & $\ddot{\mathrm{u}}$ & & $\ddot{\mathrm{u}}$ & $\begin{array}{l}\text { Interview/ } \\
\text { observation }\end{array}$ & Response to academic challenge \\
\hline $\begin{array}{l}\text { Fuller-Rowell, } \\
2015(51)\end{array}$ & 256 & & $9.2,13.1,17.5 y$ & & $\ddot{\mathrm{u}}$ & & CHAOS adapted & $\begin{array}{l}\mathrm{HC} \text { as a moderator between lower } \\
\text { SES and task persistence }\end{array}$ \\
\hline $\begin{array}{l}\text { Tomalski, } \\
2017(73)\end{array}$ & 71 & & $5.5 \mathrm{~m}$ & $\ddot{\mathrm{u}}$ & & & CHAOS long form & Processing speed \\
\hline \multicolumn{9}{|c|}{ Behavioural \& Social } \\
\hline Asbury, 2003(38) & 4706 & $\ddot{\mathrm{u}}$ & $4 y$ & $\ddot{\mathrm{u}}$ & & & CHAOS short form & $\begin{array}{l}\mathrm{HC} \text { as a mediator and moderator in } \\
\text { the relationship between parenting }\end{array}$ \\
\hline
\end{tabular}




\begin{tabular}{|c|c|c|c|c|c|c|c|c|}
\hline & & & & & & & & and behavioural outcomes \\
\hline Asbury, 2006(25) & 2017 & $\ddot{\mathrm{u}}$ & $0 \mathrm{~m}, 4 \mathrm{y}, 7 \mathrm{y}$ & & $\ddot{\mathrm{u}}$ & & CHAOS short form & $\begin{array}{l}\text { HC as moderator between non-shared } \\
\text { environment variables and anxiety, } \\
\text { hyperactivity, CP, and peer problems }\end{array}$ \\
\hline Berry, 2016(26) & 1235 & & $\begin{array}{l}2 \mathrm{~m}, 7 \mathrm{~m}, 2 \mathrm{y}, 3 \mathrm{y} \\
5 \mathrm{y}\end{array}$ & & $\ddot{\mathrm{u}}$ & $\ddot{\mathrm{u}}$ & Interview/observation & Social problems \\
\hline Bobbitt, 2016(39) & 2447 & & $\begin{array}{l}3-4 y, 3.5-4.5 y \\
\text { (6m follow-up) }\end{array}$ & & $\ddot{\mathrm{u}}$ & $\ddot{\mathrm{u}}$ & Interview/observation & Behavioural problems; social skills \\
\hline Bridgett, 2013(40) & 85 & & $4 \mathrm{~m}$ & $\ddot{\mathrm{u}}$ & & $\ddot{\mathrm{u}}$ & CHAOS long form & $\begin{array}{l}\text { HC as mediator in relationship } \\
\text { between maternal self-regulation and } \\
\text { infant negative emotionality }\end{array}$ \\
\hline Brieant, 2017(41) & 167 & & $13-14 y$ & & $\ddot{\mathrm{u}}$ & & CHAOS short form & $\begin{array}{l}\text { HC as moderator in relationship } \\
\text { between parental EF and impulsivity } \\
\text { and adolescent EF }\end{array}$ \\
\hline Brown, 2010(42) & 123 & & $4-7.5 y$ & $\ddot{\mathrm{u}}$ & & $\ddot{\mathrm{u}}$ & CHAOS long form & $\begin{array}{l}\text { Child attention (assessed by both } \\
\text { parent report and computer task) }\end{array}$ \\
\hline Calam, 2012(44) & 48 & & $2-10 y$ & $\ddot{\mathrm{u}}$ & & & CHAOS short form & Child emotional difficulties \\
\hline $\begin{array}{l}\text { Chatterjee, } \\
2015(45)\end{array}$ & 929 & & Mean 16.4y & $\ddot{\mathrm{u}}$ & & & CHAOS short form & $\begin{array}{l}\text { Substance use; sexual activity; and } \\
\text { violence-related risk behaviours }\end{array}$ \\
\hline Chen, 2014(46) & 149 & & $3-7 y$ & $\ddot{\mathrm{u}}$ & & & CHAOS short form & $\begin{array}{l}\text { Temperament-by-parenting } \\
\text { interactions } \ddagger \text { HC as moderator }\end{array}$ \\
\hline Coldwell, 2006(4) & 118 & & $4-8 y$ & $\ddot{\mathrm{u}}$ & & & CHAOS short form & $\begin{array}{l}\text { Child problem behaviour; } \mathrm{HC} \text { as a } \\
\text { moderator in relationship between } \\
\text { parenting and child behaviour }\end{array}$ \\
\hline $\begin{array}{l}\text { Deater-Deckard, } \\
2009(3)\end{array}$ & 302 & $\ddot{\mathrm{u}}$ & $4-7 y$ & & $\ddot{\mathrm{u}}$ & & CHAOS short form & $\mathrm{CP}$ \\
\hline $\begin{array}{l}\text { Dumas, } \\
\text { 2005(10) (study 1) }\end{array}$ & 106 & & $4-6 y$ & $\ddot{\mathrm{u}}$ & & & CHAOS long form & $\begin{array}{l}\text { Behaviour problems; social } \\
\text { competence; anger; aggression; } \\
\text { attention; ability to understand and } \\
\text { respond to social cues }\end{array}$ \\
\hline $\begin{array}{l}\text { Dumas, } \\
\text { 2005(10) (study 2) }\end{array}$ & 676 & & $7-11 y$ & $\ddot{\mathrm{u}}$ & & $\ddot{\mathrm{u}}$ & CHAOS long form & $\begin{array}{l}\text { Behaviour problems (caregiver and } \\
\text { teacher report) }\end{array}$ \\
\hline Evans, 2005(15) & 339 & & $\begin{array}{l}\text { Mean } 9.2 \mathrm{y} \text { at } \\
\text { baseline }\end{array}$ & & $\ddot{\mathrm{u}}$ & $\ddot{\mathrm{u}}$ & $\begin{array}{l}\text { CHAOS long form }+2 \\
\mathrm{x} \text { questions on rituals } \\
\text { and routines }\end{array}$ & $\begin{array}{l}\text { HC as mediator in relationship } \\
\text { between SES and socio-emotional } \\
\text { adjustment }\end{array}$ \\
\hline $\begin{array}{l}\text { Farbiash, } \\
2014(47)\end{array}$ & 84 & & $4 y$ at follow-up & & $\ddot{\mathrm{u}}$ & & CHAOS short form & $\begin{array}{l}\text { HC as mediator in relationship } \\
\text { between parental ADHD symptoms } \\
\text { and preschool aggression }\end{array}$ \\
\hline Fisher, 2018(81) & 390 & & $\begin{array}{l}\text { 8y at baseline, } \\
\text { 15y at follow-up }\end{array}$ & & $\ddot{\mathrm{u}}$ & & $\begin{array}{l}\text { CHAOS long form ( } 14 \\
\text { questions) }\end{array}$ & $\begin{array}{l}\text { Psychopathic characteristics; CU; } \\
\text { empathy; anxiety; aggression; } \\
\text { delinquency; classroom climate } \\
\text { quality as moderator of relationship } \\
\text { between HC and adolescent } \\
\text { outcomes }\end{array}$ \\
\hline Flouri, 2015(49) & 10,086 & & $3 y, 5 y, 7 y$ & & $\ddot{\mathrm{u}}$ & & $\begin{array}{l}3 \text { questions from } \\
\text { CHAOS }+2 \text { questions } \\
\text { about bedtime and } \\
\text { mealtimes }\end{array}$ & $\begin{array}{l}\text { Occupational aspirations at age } 7 \\
\text { years }\end{array}$ \\
\hline Flouri, 2017(48) & 180 & & $3 y, 5 y, 7 y, 11 y$ & & $\ddot{\mathrm{u}}$ & & $3 \mathrm{x}$ CHAOS questions & $\begin{array}{l}\text { HC as mediator in relationship } \\
\text { between low SES and CP in children } \\
\text { with ADHD }\end{array}$ \\
\hline Fontaine, & 9,578 & & $4 y, 7 y, 12 y$ & & $\ddot{\mathrm{u}}$ & & CHAOS short form & $\mathrm{CP}$; CU traits \\
\hline
\end{tabular}




\begin{tabular}{|c|c|c|c|c|c|c|c|c|}
\hline 2011(50) & & & & & & & & \\
\hline Gould, 2017(52) & 520 & $\ddot{\mathrm{u}}$ & $6-15 y$ & & $\ddot{\mathrm{u}}$ & & CHAOS short form & $\begin{array}{l}\text { HC as moderator of relationship } \\
\text { between genes and development of } \\
\text { ADHD }\end{array}$ \\
\hline Gregory, 2005(53) & 6612 & & $3 y, 4 y$ & & $\ddot{\mathrm{u}}$ & & CHAOS short form & $\begin{array}{l}\text { Anxiety; } \mathrm{HC} \text { as mediator of } \\
\text { relationship between sleep problems } \\
\text { and anxiety }\end{array}$ \\
\hline $\begin{array}{l}\text { Gunzenhauser, } \\
2017(54)\end{array}$ & 263 & & Mean 8.59y & & $\ddot{\mathrm{u}}$ & & CHAOS long form & Self-regulation \\
\hline $\begin{array}{l}\text { Hannigan, } \\
2017(55)\end{array}$ & 6646 & $\ddot{\mathrm{u}}$ & $9 y, 12 y, 14,16 y$ & & $\ddot{\mathrm{u}}$ & & CHAOS short form & Depressive symptoms \\
\hline $\begin{array}{l}\text { Hardaway, } \\
2012(56)\end{array}$ & 731 & & Mean 3.4y & & $\ddot{\mathrm{u}}$ & $\ddot{\mathrm{u}}$ & CHAOS long form & $\begin{array}{l}\text { Inhibitory control; problem behaviour; } \\
\text { aggression }\end{array}$ \\
\hline Human, 2016(57) & 261 & & $\begin{array}{c}\text { 13-16y at } \\
\text { baseline (2-year } \\
\text { follow-up) }\end{array}$ & & $\ddot{\mathrm{u}}$ & & CHAOS long form & $\begin{array}{l}\text { Depressive symptoms; perceived } \\
\text { stress }\end{array}$ \\
\hline Hur, 2015(29) & 444 & & $36-70 \mathrm{~m}$ & $\ddot{\mathrm{u}}$ & & & CHAOS short form & $\begin{array}{l}\text { HC as mediator between parent } \\
\text { depressive symptoms and child socio- } \\
\text { emotional development, and } \\
\text { behavioural self-regulation }\end{array}$ \\
\hline Jaffee, 2012(58) & 6286 & $\ddot{\mathrm{u}}$ & $9 y, 12 y$ & & $\ddot{\mathrm{u}}$ & & CHAOS short form & $\mathrm{CP}$; hyperactivity-inattention \\
\hline Kahn, 2016(59) & 115 & & Mean 13.97y & $\ddot{\mathrm{u}}$ & & & CHAOS short form & $\begin{array}{l}\text { Moderated mediation analysis }= \\
\text { Harsh parenting as a mediator in the } \\
\text { relationship between parent CU traits } \\
\text { and child CU traits, and then } \mathrm{HC} \text { as a } \\
\text { moderator of this relationship }\end{array}$ \\
\hline $\begin{array}{l}\text { Kim-Spoon, } \\
2017(60)\end{array}$ & 167 & & $13-14 y$ & & $\ddot{\mathrm{u}}$ & & CHAOS short form & $\begin{array}{l}\text { HC as moderator of relationship } \\
\text { between parental control and social } \\
\text { competence }\end{array}$ \\
\hline $\begin{array}{l}\text { Lauharatanahirun, } \\
\text { 2018(82) }\end{array}$ & 167 & & 13-15 years & & $\ddot{\mathrm{u}}$ & & CHAOS short form & $\begin{array}{l}\text { HC as moderator between parental } \\
\text { knowledge and insular risk processing }\end{array}$ \\
\hline Laurent, 2014(61) & 200 & & $\begin{array}{c}9 \mathrm{~m}, 18 \mathrm{~m}, 27 \mathrm{~m}, \\
4.5 \mathrm{y}, 6 \mathrm{y}\end{array}$ & & $\ddot{\mathrm{u}}$ & & CHAOS short form & $\begin{array}{l}\text { Behaviour problems in adopted } \\
\text { children }\end{array}$ \\
\hline $\begin{array}{l}\text { Lemery-Chalfant, } \\
\text { 2013(62) }\end{array}$ & 807 & $\ddot{\mathrm{u}}$ & Mean 7.93y & $\ddot{\mathrm{u}}$ & & & CHAOS short form & $\begin{array}{l}\text { Genes as mediator in relationship } \\
\text { between HC and child temperament } \\
\text { (passive gene-environment); HC as } \\
\text { moderator in relationship between } \\
\text { genes and child temperament }\end{array}$ \\
\hline Martin, 2012(6) & 1266 & & $2.5 y, 5 y$ & & $\ddot{\mathrm{u}}$ & & $\begin{array}{l}\text { Questionnaire } \\
\text { designed for study }\end{array}$ & $\begin{array}{l}\text { Attention; aggression; delayed } \\
\text { gratification; Mediating role of } \\
\text { maternal warmth and provision of } \\
\text { learning materials in the home on the } \\
\text { relationship between lack of routines } \\
\text { and delayed gratification }\end{array}$ \\
\hline $\begin{array}{l}\text { Midouhas, } \\
\text { 2013(63) }\end{array}$ & 209 & & $9 \mathrm{~m}, 3 \mathrm{y}, 5 \mathrm{y}, 7 \mathrm{y}$ & & $\ddot{\mathrm{u}}$ & & $\begin{array}{l}3 \text { items from the } \\
\text { CHAOS short form }\end{array}$ & $\begin{array}{l}\mathrm{CP} \text { in children with autism; } \mathrm{HC} \text { as } \\
\text { moderator of relationship between } \\
\text { poverty and parenting, and } \\
\text { psycopathology in children with } \\
\text { autism }\end{array}$ \\
\hline Miller, 2017(64) & 380 & & Preschool (USA) & $\ddot{\mathrm{u}}$ & & $\ddot{\mathrm{u}}$ & CHAOS long form & Negative liability; emotion regulation \\
\hline Mills-Koonce, & $\sim 1292$ & & $2 \mathrm{~m}, 6 \mathrm{~m}, 15 \mathrm{~m}$ & & $\ddot{\mathrm{u}}$ & $\ddot{\mathrm{u}}$ & Interview/observation & CU; CP; empathy; HC as moderator in \\
\hline
\end{tabular}




\begin{tabular}{|c|c|c|c|c|c|c|c|c|}
\hline 2016(65) & & & $\begin{array}{l}24 \mathrm{~m}, 36 \mathrm{~m} \text {, first } \\
\text { grade }\end{array}$ & & & & & $\begin{array}{l}\text { relationship between parenting and } \\
\text { child behaviours; Maternal sensitivity } \\
\text { and harsh parenting as mediators in } \\
\text { relationship between HC and child } \\
\text { behaviour }\end{array}$ \\
\hline Oliver, 2008(66) & 285 & $\ddot{\mathrm{u}}$ & $8-10 y$ & $\ddot{\mathrm{u}}$ & & & CHAOS short form & $\begin{array}{l}\text { HC as moderator in relationship } \\
\text { between within-pair differences in } \\
\text { perceptions of the classroom } \\
\text { environment and teacher report of } \\
\text { less prosocial and more hyperactive } \\
\text { behaviour, and greater conduct and } \\
\text { peer problems }\end{array}$ \\
\hline Panico, 2014(67) & 6572 & & $3 y, 5 y$ & & $\ddot{\mathrm{u}}$ & & 3 items from CHAOS & Behavioural outcomes \\
\hline Pike, 2006(30) & 5765 & & $0-3 y, 4 y$ & & & & CHAOS short form & Behavioural outcomes \\
\hline Raver, 2015(68) & 1025 & & $\begin{array}{l}\text { Followed } \\
\text { between } 6 \mathrm{~m} \text { and } \\
58 \mathrm{~m}\end{array}$ & & $\ddot{\mathrm{u}}$ & $\ddot{\mathrm{u}}$ & $\begin{array}{l}\text { Interview/ } \\
\text { observation }\end{array}$ & $\begin{array}{l}\text { Ability to recognise and modulate } \\
\text { negative emotions }\end{array}$ \\
\hline $\begin{array}{l}\text { Shamama-tus- } \\
\text { Sabah, 2011(32) }\end{array}$ & 101 & & $8-11 y$ & $\ddot{\mathrm{u}}$ & & & CHAOS long form & Attention \\
\hline $\begin{array}{l}\text { Shamama-tus- } \\
\text { Sabah, 2011(69) }\end{array}$ & 203 & & $8-11 y$ & $\ddot{\mathrm{u}}$ & & & CHAOS long form & $\mathrm{CP}$ \\
\hline $\begin{array}{l}\text { Shamama-tus- } \\
\text { Sabah, 2011(33) }\end{array}$ & 203 & & $8-11 y$ & $\ddot{\mathrm{u}}$ & & & CHAOS long form & $\begin{array}{l}\text { Internalising and externalising } \\
\text { behaviours }\end{array}$ \\
\hline $\begin{array}{l}\text { Shamama-tus- } \\
\text { Sabah, 2011(34) }\end{array}$ & 101 & & $8-11 y$ & $\ddot{\mathrm{u}}$ & & & CHAOS long form & Adjustment problems \\
\hline Shapero, 2013(70) & 956 & & $\begin{array}{c}\text { Followed } \\
\text { between birth } \\
\text { and } 15 \mathrm{y}\end{array}$ & & $\ddot{\mathrm{u}}$ & & CHAOS long form & $\begin{array}{l}\text { Changes in emotional and behavioural } \\
\text { problems between childhood and } \\
\text { adolescence }\end{array}$ \\
\hline Shelleby, 2014(71) & 731 & & $\begin{array}{l}2-3 y, 4-5 y, 7.5- \\
8.5 y\end{array}$ & & $\ddot{\mathrm{u}}$ & $\ddot{\mathrm{u}}$ & CHAOS long form & $\begin{array}{l}\text { HC as mediator in relationship } \\
\text { between income and emotional } \\
\text { problems and CP }\end{array}$ \\
\hline Supplee, 2007(72) & 120 & & $2,3,4 \& 5 y$ & & $\ddot{\mathrm{u}}$ & $\ddot{\mathrm{u}}$ & CHAOS long form & $\begin{array}{l}\text { Externalising behaviours; Maternal } \\
\text { monitoring as moderator in } \\
\text { relationship between HC and } \\
\text { externalising behaviours }\end{array}$ \\
\hline $\begin{array}{l}\text { Towe-Goodman, } \\
\text { 2011(74) }\end{array}$ & 636 & & $\begin{array}{l}\text { Infant, toddler, } \\
\qquad 3 \mathrm{y}\end{array}$ & & $\ddot{\mathrm{u}}$ & $\ddot{\mathrm{u}}$ & CHAOS long form & $\begin{array}{l}\text { HC as moderator in relationship } \\
\text { between interparental aggression in } \\
\text { toddlerhood and the development of } \\
\text { child attention skills and early } \\
\text { childhood behaviour problems at age } \\
3 \text { years, in low-income families }\end{array}$ \\
\hline Tucker, 2015(75) & 325 & & Mean 15.71y & $\ddot{\mathrm{u}}$ & & & CHAOS short form & $\begin{array}{l}\text { Adolescents' future beliefs; Mother's } \\
\text { hostility as moderator in relationship } \\
\text { between HC and adolescents' future } \\
\text { beliefs }\end{array}$ \\
\hline Tucker, 2018(83) & 238 & & $\begin{array}{l}\text { Followed } \\
\text { between } 10^{\text {th }} \\
\text { grade (mean } \\
\text { 15.59y) and } 12^{\text {th }} \\
\text { grade }\end{array}$ & & $\ddot{\mathrm{u}}$ & $\ddot{\mathrm{u}}$ & CHAOS short form & $\begin{array}{l}\text { Problematic substance use, } \\
\text { depression; HC as moderator in } \\
\text { relationship between hostile } \\
\text { parenting and depression }\end{array}$ \\
\hline Valiente, 2007(76) & 188 & & $7-12 y$ & $\ddot{\mathrm{u}}$ & & & CHAOS short form & $\begin{array}{l}\text { Effortful control; externalising } \\
\text { behaviours }\end{array}$ \\
\hline
\end{tabular}




\begin{tabular}{|c|c|c|c|c|c|c|c|c|}
\hline $\begin{array}{l}\text { Vernon-Feagans, } \\
2016(77)\end{array}$ & 1145 & & $\begin{array}{l}2,6,15,24,48 \\
\& 60 \text { months }\end{array}$ & & $\ddot{\mathrm{u}}$ & $\ddot{\mathrm{u}}$ & Interview/observation & $\begin{array}{l}\text { Regulatory behaviours in } \\
\text { kindergarten; Parenting and } \\
\text { executive function as mediators of } \\
\text { the relationship between HC and } \\
\text { behaviours }\end{array}$ \\
\hline Vilsaint, 2013(78) & 364 & & $2 y, 5 y$ & & $\ddot{\mathrm{u}}$ & $\ddot{\mathrm{u}}$ & CHAOS long form & $\begin{array}{l}\text { Internalising \& externalising } \\
\text { behaviours }\end{array}$ \\
\hline Vrijhof, 2018(84) & 201 & $\ddot{\mathrm{u}}$ & $34-66 \mathrm{~m}$ & $\ddot{\mathrm{u}}$ & & & CHAOS long from & Effortful control; cheating behaviour \\
\hline Wang, 2012(79) & 304 & $\ddot{\mathrm{u}}$ & $\begin{array}{l}\text { Mean 6.07y, } \\
7.15 \mathrm{y}, \& 8.30 \mathrm{y}\end{array}$ & & $\ddot{\mathrm{u}}$ & & CHAOS short form & $\begin{array}{l}\text { HC as moderator in the genetic link } \\
\text { between attention regulation and } \\
\text { externalising behaviours }\end{array}$ \\
\hline $\begin{array}{l}\text { Wilkinson, } \\
\text { 2013(80) }\end{array}$ & $\sim 8800$ & $\ddot{\mathrm{u}}$ & $\begin{array}{l}2,6,15,24,48 \\
\& 60 \text { months }\end{array}$ & & $\ddot{\mathrm{u}}$ & & CHAOS short form & $\begin{array}{l}\text { HC as moderator in relationship } \\
\text { between genes and depressive } \\
\text { symptoms (Gene } \times \text { Environment } \\
\text { interaction) }\end{array}$ \\
\hline \multicolumn{9}{|c|}{ COMMUNICATION $(6,7,24,26,85,86)$} \\
\hline Asbury, 2005(85) & 2223 & $\ddot{\mathrm{u}}$ & $4 y$ & $\ddot{\mathrm{u}}$ & & & CHAOS short form & $\begin{array}{l}\text { Verbal and non-verbal abilities; } \mathrm{HC} \text { as } \\
\text { moderator in the heritability of verbal } \\
\text { and non-verbal abilities }\end{array}$ \\
\hline Berry, 2016(26) & 1235 & & $\begin{array}{l}2 \mathrm{~m}, 7 \mathrm{~m}, 2 \mathrm{y}, 3 \mathrm{y} \\
5 \mathrm{y}\end{array}$ & & $\ddot{\mathrm{u}}$ & $\ddot{\mathrm{u}}$ & Interview/observation & Receptive vocab \\
\hline Johnson, 2008(7) & 455 & $\ddot{\mathrm{u}}$ & mean 6.1 years & & & & CHAOS short form & $\begin{array}{l}\text { Expressive vocab and phonological } \\
\text { awareness }\end{array}$ \\
\hline Martin, 2012(6) & 1266 & & $2.5 y, 5 y$ & & $\ddot{\mathrm{u}}$ & & $\begin{array}{l}\text { Questions designed } \\
\text { for study }\end{array}$ & $\begin{array}{l}\text { Receptive vocab; Mediating role of } \\
\text { provision of learning materials in the } \\
\text { home on the relationship between } \\
\text { lack of routines and receptive vocab }\end{array}$ \\
\hline Petrill, 2004(24) & & $\ddot{\mathrm{u}}$ & $3 \& 4 y$ & & $\ddot{\mathrm{u}}$ & & CHAOS short form & $\begin{array}{l}\text { Verbal and non-verbal abilities; HC as } \\
\text { mediator in relationship between } \\
\text { shared environment and verbal and } \\
\text { non-verbal scores }\end{array}$ \\
\hline $\begin{array}{l}\text { Vernon-Feagans, } \\
\text { 2012(86) }\end{array}$ & 1145 & & $\begin{array}{c}2,6,15,24, \& \\
36 \mathrm{~m}\end{array}$ & & $\ddot{\mathrm{u}}$ & $\ddot{\mathrm{u}}$ & Interview/observation & Receptive and expressive language \\
\hline \multicolumn{9}{|c|}{ PARENTING, FAMILY \& HOUSEHOLD FUNCTIONING(4, 10, 46, 76, 86-102) } \\
\hline \multicolumn{9}{|l|}{ Parenting } \\
\hline $\begin{array}{l}\text { Atzaba-Poria, } \\
\text { 2008(87) }\end{array}$ & 344 & & $\begin{array}{l}\text { 4-5y and an } \\
\text { older sibling } \\
\text { aged }<=8 y\end{array}$ & $\ddot{\mathrm{u}}$ & & & CHAOS short form & Differential parenting \\
\hline Barnes, 2014(88) & 24,610 & & 3y & $\ddot{\mathrm{u}}$ & & & $\begin{array}{l}3 \text { questions from } \\
\text { CHAOS }\end{array}$ & $\begin{array}{l}\text { Parent/child conflict \& closeness; } \\
\text { home learning environment; parenting }\end{array}$ \\
\hline Chen, 2014(46) & 149 & & $3-7 y$ & $\ddot{\mathrm{u}}$ & & & CHAOS short form & $\begin{array}{l}\text { Temperament-by-parenting } \\
\text { interactionsł; HC as a moderator }\end{array}$ \\
\hline Coldwell, 2006(4) & 118 & & $4-8 y$ & $\ddot{\mathrm{u}}$ & & & CHAOS short form & Parenting \\
\hline Corapci, 2002(89) & 57 & & $12-14 \mathrm{~m}$ & $\ddot{\mathrm{u}}$ & & & CHAOS long form & $\begin{array}{l}\text { Parenting; Parental self-efficacy and } \\
\text { parent negative mood as mediators in } \\
\text { relationship between HC and } \\
\text { parenting }\end{array}$ \\
\hline $\begin{array}{l}\text { Deater-Deckard, } \\
\text { 2012(90) }\end{array}$ & 147 & & $3-7 y$ & $\ddot{\mathrm{u}}$ & & & CHAOS short form & $\begin{array}{l}\text { HC as a moderator of maternal EF, } \\
\text { which itself was assessed as a }\end{array}$ \\
\hline
\end{tabular}




\begin{tabular}{|c|c|c|c|c|c|c|c|}
\hline & & & & & & & $\begin{array}{l}\text { moderator in the relationship } \\
\text { between child CP and harsh parenting }\end{array}$ \\
\hline $\begin{array}{l}\text { Dumas, } \\
\text { 2005(10) (study 1) }\end{array}$ & 106 & $4-6 y$ & $\ddot{\mathrm{u}}$ & & & CHAOS long form & $\begin{array}{l}\text { Parental discipline, and accuracy and } \\
\text { efficiency in a co-operative parent- } \\
\text { child interactional task }\end{array}$ \\
\hline $\begin{array}{l}\text { Kretschmer, } \\
2009(92)\end{array}$ & 118 & $4-8 y$ & $\ddot{\mathrm{u}}$ & & & CHAOS short form & $\begin{array}{l}\text { Sibling relationships; Parenting as a } \\
\text { mediator and moderator in the } \\
\text { relationship between HC and sibling } \\
\text { relationships }\end{array}$ \\
\hline $\begin{array}{l}\text { Mokrova, } \\
\text { 2010(93) }\end{array}$ & 319 & $\begin{array}{l}7 \mathrm{y}(\text { group } 1) \& \\
10 \mathrm{y}(\text { group } 2)\end{array}$ & $\ddot{\mathrm{u}}$ & & & CHAOS long form & $\begin{array}{l}\text { HC as mediator and moderator in } \\
\text { relationships between maternal and } \\
\text { paternal ADHD symptoms and } \\
\text { parenting }\end{array}$ \\
\hline Nelson, 2009(94) & 101 & $7 y$ & $\ddot{\mathrm{u}}$ & & & CHAOS long form & $\begin{array}{l}\text { Parental supportive and } \\
\text { nonsupportive responses to child }\end{array}$ \\
\hline Pike, 2016(95) & 106 & $\begin{array}{c}\text { Siblings aged } \\
\text { 4-8 years at } \\
\text { baseline \& 9-13 } \\
\text { years at follow- } \\
\text { up }\end{array}$ & & $\ddot{\mathrm{u}}$ & & CHAOS short form & $\begin{array}{l}\text { Siblings' perceptions of mothering } \\
\text { and fathering }\end{array}$ \\
\hline $\begin{array}{l}\text { Spilsbury, } \\
2017(97)\end{array}$ & 26 & $11-12 y$ & $\ddot{\mathrm{u}}^{\alpha}$ & & & CHAOS long form & $\begin{array}{l}\text { Sleep-disturbing behaviours of family } \\
\text { members }\end{array}$ \\
\hline Valiente, 2007(76) & 188 & $7-12 y$ & $\ddot{\mathrm{u}}$ & & & CHAOS short form & $\begin{array}{l}\text { Positive and negative reactions to } \\
\text { child's negative emotions }\end{array}$ \\
\hline $\begin{array}{l}\text { Vernon-Feagans, } \\
2012(86)\end{array}$ & 1123 & $\begin{array}{c}2,6,15,24, \& \\
36 \mathrm{~m}\end{array}$ & & $\ddot{\mathrm{u}}$ & $\ddot{\mathrm{u}}$ & $\begin{array}{l}\text { Interview/ } \\
\text { observation }\end{array}$ & $\begin{array}{l}\text { Parenting as a mediator in the } \\
\text { relationship between HC and } \\
\text { language development }\end{array}$ \\
\hline Wang, 2013(98) & 160 & $3-7 y$ & $\ddot{\mathrm{u}}$ & & & CHAOS short form & $\begin{array}{l}\text { HC as a moderator in relationship } \\
\text { between maternal attribution bias } \\
\text { (e.g. whether they attribute child } \\
\text { misbehaviour to the child's intentions } \\
\text { and dismiss situational factors) and } \\
\text { parenting behaviour }\end{array}$ \\
\hline $\begin{array}{l}\text { Whitesell, } \\
\text { 2015(99) }\end{array}$ & 100 & $1,3,6,9, \& 12 \mathrm{~m}$ & & $\ddot{\mathrm{u}}$ & & $\begin{array}{l}\text { DISCORD - an } \\
\text { observer reported } \\
\text { measure of HC }\end{array}$ & $\begin{array}{l}\text { SES; life events; co-parenting; } \\
\text { emotional availability at bedtime }\end{array}$ \\
\hline Wirth, 2017(100) & 84 & $7-13 y$ & & & & CHAOS long form & $\begin{array}{l}\text { HC as mediator in relationship } \\
\text { between children's ADHD symptoms } \\
\text { and inadequate parenting }\end{array}$ \\
\hline Zvara, 2014(101) & 962 & $\begin{array}{l}2,6,15,24,60 \\
\text { months \& } 1^{\text {st }} \\
\text { grade }\end{array}$ & & $\ddot{\mathrm{u}}$ & $\ddot{\mathrm{u}}$ & $\begin{array}{l}\text { Interview/ } \\
\text { observation }\end{array}$ & $\begin{array}{l}\text { Children's representations of family } \\
\text { dysfunction from drawings; mediating } \\
\text { role of parenting in relationship } \\
\text { between HC and family dysfunction }\end{array}$ \\
\hline \multicolumn{8}{|c|}{ Household Characteristics and Food Security } \\
\hline Fiese, 2016(91) & 221 & $\begin{array}{l}\text { Elementary } \\
\text { school (USA) }\end{array}$ & $\ddot{\mathrm{u}}$ & & $\ddot{\mathrm{u}}$ & CHAOS short form & Food security \\
\hline $\begin{array}{l}\text { Martin-Biggers, } \\
\text { 2018(102) }\end{array}$ & 550 & $2-5 y$ & $\ddot{\mathrm{u}}$ & & & CHAOS short form & $\begin{array}{l}\text { Family meals; food } \\
\text { availability/security; family meal } \\
\text { atmosphere }\end{array}$ \\
\hline Pinard, 2015(96) & 252 & $0-18 y$ & $\ddot{\mathrm{u}}$ & & $\ddot{\mathrm{u}}$ & CHAOS short form & Food security \\
\hline \multicolumn{8}{|c|}{ PARENT OUTCOMES $(12,102-106)$} \\
\hline Deater-Deckard, & 153 & $33-88 \mathrm{~m} \dagger$ & $\ddot{\mathrm{u}}$ & & & CHAOS short form & Maternal EF; SES as moderator of \\
\hline
\end{tabular}




\begin{tabular}{|c|c|c|c|c|c|c|c|}
\hline 2012(12) & & & & & & & $\begin{array}{l}\text { relationship between } \mathrm{HC} \text { and } \\
\text { maternal EF }\end{array}$ \\
\hline $\begin{array}{l}\text { MacRae, } \\
\text { 2017(103) }\end{array}$ & 44 & $10-5 y \dagger$ & $\ddot{\mathrm{u}}$ & & & CHAOS long form & Parent fat intake and cortisol levels \\
\hline $\begin{array}{l}\text { Madigan, } \\
2017(104)\end{array}$ & 501 & $2-54 m+$ & & $\ddot{\mathrm{u}}$ & & $\begin{array}{l}\text { Adapted version of the } \\
\text { HOME scale }\end{array}$ & Maternal depression trajectories \\
\hline $\begin{array}{l}\text { Martin-Biggers, } \\
\text { 2018(102) }\end{array}$ & 550 & $2-5 y$ & $\ddot{\mathrm{u}}$ & & & CHAOS short form & $\begin{array}{l}\text { Maternal eating behaviours; weight } \\
\text { status; health status }\end{array}$ \\
\hline $\begin{array}{l}\text { Thomas, } \\
\text { 2016(105) }\end{array}$ & 42 & 32wkst & $\ddot{\mathrm{u}}$ & & & CHAOS long form & $\begin{array}{l}\text { Maternal depression, fatigue, and } \\
\text { sleep }\end{array}$ \\
\hline $\begin{array}{l}\text { Whitesell, } \\
\text { 2018(106) }\end{array}$ & 167 & $1,3,6,9,12 \mathrm{~m}$ & & $\ddot{\mathrm{u}}$ & & DISCORD & Parent sleep \\
\hline \multicolumn{8}{|c|}{ HORMONE(61, 107-113) } \\
\hline Blair, 2013(107) & 1292 & $\begin{array}{c}2,7,24, \& 36 \mathrm{mo} \\
5 \mathrm{y}\end{array}$ & & $\ddot{\mathrm{u}}$ & $\ddot{\mathrm{u}}$ & $\begin{array}{l}\text { Interview/ } \\
\text { observation }\end{array}$ & Cortisol and ANS activity \\
\hline Chen, 2010(108) & 50 & $9-18 y$ & & $\ddot{\mathrm{u}}$ & $\ddot{\mathrm{u}}$ & CHAOS long form & $\begin{array}{l}\text { HC as mediator in the relationship } \\
\text { between low SES and cortisol profiles }\end{array}$ \\
\hline Doom, 2018(113) & 242 & $\begin{array}{l}35-62,38-85,84- \\
122 \mathrm{~m}\end{array}$ & & $\ddot{\mathrm{u}}$ & $\ddot{\mathrm{u}}$ & CHAOS long form & $\begin{array}{l}\text { Diurnal cortisol levels in response to } \\
\text { social stress test }\end{array}$ \\
\hline Laurent, 2014(61) & 200 & $\begin{array}{c}9 \mathrm{~m}, 18 \mathrm{~m}, 27 \mathrm{~m} \\
4.5 \mathrm{y}, 6 \mathrm{y}\end{array}$ & & $\ddot{\mathrm{u}}$ & & CHAOS short form & $\begin{array}{l}\text { Developmental stability of } \\
\text { hypothalamic-pituitary-adrenal (HPA) } \\
\text { axis activity }\end{array}$ \\
\hline $\begin{array}{l}\text { Lumeng, } \\
\text { 2014(109) }\end{array}$ & 331 & $3-4 y$ & $\ddot{\mathrm{u}}$ & & $\ddot{\mathrm{u}}$ & CHAOS long form & Morning cortisol levels \\
\hline Miller, 2013(110) & 34 & $3-4 y$ & $\ddot{\mathrm{u}}$ & & $\ddot{\mathrm{u}}$ & CHAOS long form & Gut biomarkers \\
\hline $\begin{array}{l}\text { O’Brien, } \\
\text { 2013(111) }\end{array}$ & 135 & 18-66y & $\ddot{\mathrm{u}}$ & & & CHAOS short form & Stress \\
\hline $\begin{array}{l}\text { Schreier, } \\
2014(112)\end{array}$ & 244 & 13-16y & $\ddot{u}$ & & & CHAOS long form & Inflammatory profile \\
\hline \multicolumn{8}{|c|}{ PHYSICAL HEALTH, HEALTH BEHAVIOURS \& COMMUNICATION DISORDERS $(13,14,53,83,97,102,106,109,114-124)$} \\
\hline \multicolumn{8}{|c|}{ Health/Disease/Disorder Outcomes } \\
\hline $\begin{array}{l}\text { Appelhans, } \\
\text { 2014(13) }\end{array}$ & 103 & $6-13 y$ & $\ddot{\mathrm{u}}$ & & $\ddot{\mathrm{u}}$ & CHAOS long form & $\begin{array}{l}\text { HC as mediator in relationship } \\
\text { between sleep duration and child } \\
\text { weight }\end{array}$ \\
\hline Chae, 2016(114) & 125 & Mean 12.6y & $\ddot{\mathrm{u}}$ & & & CHAOS long form & HbA1c \\
\hline Dush, 2013(115) & 3288 & $3 y, 5 y$ & & $\ddot{\mathrm{u}}$ & $\ddot{\mathrm{u}}$ & $\begin{array}{l}\text { Interview/ } \\
\text { observation }\end{array}$ & Child health \\
\hline $\begin{array}{l}\text { Khatiwada, } \\
\text { 2018(118) }\end{array}$ & 401 & $\begin{array}{l}\text { Infants; followed } \\
\text { during first } 12 \\
\text { mo }\end{array}$ & & $\ddot{\mathrm{u}}$ & & CHAOS long form & Weight status \\
\hline Kraft, 2014(117) & 69 & Mean 3.7y & $\ddot{\mathrm{u}}$ & & & CHAOS long form & Stuttering severity \\
\hline Levin, 2013(116) & 104 & $1-13 y$ & & $\ddot{\mathrm{u}}$ & & CHAOS long form & HbA1c \\
\hline $\begin{array}{l}\text { Lumeng, } \\
2014(109)\end{array}$ & 331 & $3-4 y$ & $\ddot{\mathrm{u}}$ & & $\ddot{\mathrm{u}}$ & CHAOS long form & Overweight \\
\hline $\begin{array}{l}\text { Martin-Biggers, } \\
\text { 2018(102) }\end{array}$ & 550 & $2-5 y$ & $\ddot{\mathrm{u}}$ & & & CHAOS short form & Health status; weight status \\
\hline Tucker, 2018(83) & 238 & $\begin{array}{c}\text { Followed } \\
\text { between } 10^{\text {th }} \\
\text { grade (mean at } \\
\text { baseline } 15.59 y \text { ) } \\
\text { and } 12^{\text {th }} \text { grade }\end{array}$ & & $\ddot{\mathrm{u}}$ & $\ddot{\mathrm{u}}$ & CHAOS short form & $\begin{array}{l}\text { Physical health symptoms; } \mathrm{HC} \text { as } \\
\text { moderator in relationship between } \\
\text { hostile parenting and physical health } \\
\text { symptoms }\end{array}$ \\
\hline
\end{tabular}




\begin{tabular}{|c|c|c|c|c|c|c|c|}
\hline Asta, 2016(119) & 209 & $21,27, \& 33 \mathrm{~m}$ & & $\ddot{\mathrm{u}}$ & $\ddot{\mathrm{u}}$ & $\begin{array}{l}\text { CHAOS (not } \\
\text { specified) }\end{array}$ & Eating in the absence of hunger \\
\hline $\begin{array}{l}\text { Goulding, } \\
2015(120)\end{array}$ & 287 & $4-8 y$ & $\ddot{\mathrm{u}}$ & & $\ddot{\mathrm{u}}$ & CHAOS long form & Maternal feeding goals \\
\hline $\begin{array}{l}\text { Martin-Biggers, } \\
\text { 2018(102) }\end{array}$ & 550 & $2-5 y$ & $\ddot{\mathrm{u}}$ & & & CHAOS short form & Food-related behaviours \\
\hline \multicolumn{8}{|l|}{ Sleep } \\
\hline Bartel, 2016(121) & 1402 & $12-19 y$ & $\ddot{\mathrm{u}}$ & & & CHAOS short form & Sleep \\
\hline Billows, 2009(122) & 217 & $13-18 y$ & $\ddot{\mathrm{u}}$ & & & CHAOS long form & Sleep \\
\hline Boles, 2017(14) & 72 & Mean 4.7y & $\ddot{\mathrm{u}}$ & & $\ddot{\mathrm{u}}$ & CHAOS long form & $\begin{array}{l}\text { Sleep; } \mathrm{HC} \text { as a mediator in } \\
\text { relationship between behaviour and } \\
\text { sleep outcomes. }\end{array}$ \\
\hline Gregory, 2005(53) & 6612 & $3 y, 4 y$ & & $\ddot{\mathrm{u}}$ & & CHAOS short form & $\begin{array}{l}\text { Sleep; HC as mediator relationship } \\
\text { between sleep problems and anxiety }\end{array}$ \\
\hline $\begin{array}{l}\text { Spilsbury, } \\
2017(97)\end{array}$ & 26 & $11-12 y$ & $\ddot{\mathrm{u}}^{\alpha}$ & & & CHAOS long form & Sleep \\
\hline $\begin{array}{l}\text { Whitesell, } \\
\text { 2018(106) }\end{array}$ & 167 & $1,3,6,9,12 \mathrm{~m}$ & & $\ddot{\mathrm{u}}$ & & DISCORD & Sleep \\
\hline \multicolumn{8}{|c|}{ Other Health Behaviours/Outcomes } \\
\hline Brown, 2010(123) & 70 & $4-7.5 y$ & $\ddot{\mathrm{u}}$ & & $\ddot{\mathrm{u}}$ & CHAOS long form & $\begin{array}{l}\text { TV viewing behaviours in a laboratory } \\
\text { setting }\end{array}$ \\
\hline Pesch, 2015(124) & 278 & $4-8 y$ & $\ddot{\mathrm{u}}$ & & $\ddot{\mathrm{u}}$ & CHAOS long form & $\begin{array}{l}\text { Maternal perceptions about physical } \\
\text { activity. }\end{array}$ \\
\hline
\end{tabular}

*No. of studies reported in manuscript; **Age for cross-sectional/other study type presented as range (preferential; based on inclusion criteria), mean (if range not given), or age group (if specific age not provided; when age group is used the country where the study took place is also included, as definitions of age groups differ between countries); for longitudinal studies age at each follow-up was provided where available for range, mean, or age group; ${ }^{* * *}$ If multiple selected, then cross-sectional and longitudinal analyses conducted. CHAOS short- and long-form refer to the short-form(24) and long-form (23) versions of the Confusion, Hubbub, and Order Scale (CHAOS).

‡Temperament-parenting-interactions = interactions between child temperament and parenting (i.e. maternal negativity and positivity); ${ }^{\alpha}$ Reported as longitudinal but conducted as a 14-week laboratory sleep study; †Age of the child. $\mathrm{C} / \mathrm{O}=\mathrm{Cross}$-sectional/other; $\mathrm{L}=\mathrm{Longitudinal}$; $\mathrm{HC}=$ Household Chaos; $\mathrm{EF}$ = executive function; $\mathrm{CP}=$ conduct problems; $\mathrm{CU}=$ callous-unemotional traits; ANS = autonomic nervous system. 


\begin{tabular}{|c|c|c|}
\hline STUDY & HC AS MEDIATOR & HC AS MODERATOR \\
\hline $\begin{array}{l}\text { Appelhans, } \\
\text { 2014(13) }\end{array}$ & $\begin{array}{l}\text { The only health behaviour significantly } \\
\text { associated with child bodyweight was sleep. } \\
\text { HC partially mediated the relationship } \\
\text { between child sleep and bodyweight. }\end{array}$ & \\
\hline Asbury, 2003(38) & $\begin{array}{l}\text { HC did not mediate the relationship } \\
\text { between parenting and behavioural } \\
\text { outcomes. }\end{array}$ & $\begin{array}{l}\text { HC significantly moderated the relationship between (1) differential harsh } \\
\text { parental discipline and differential CP, and (2) differential negative } \\
\text { parental feelings and anxiety, hyperactivity, and CP. That is, the } \\
\text { relationship between NSE influences (i.e. differential parenting) and } \\
\text { behavioural outcomes were stronger in high chaos homes. }\end{array}$ \\
\hline Asbury, 2006(25) & & $\begin{array}{l}\text { HC moderated the relationship between: (1) discordant harsh discipline } \\
\text { and CP [increase in CP], (2) discordant negative feelings and CP [increase } \\
\text { in CP], (3) discordant parental negative feelings and academic } \\
\text { achievement [achievement decreased], and (4) instructive parent-child } \\
\text { communication and anxiety [anxiety increased] (where instructive } \\
\text { communication including things like correcting child's grammar) }\end{array}$ \\
\hline Boles, 2017(14) & $\begin{array}{l}\text { Children with higher scores for emotional } \\
\text { and behaviour problems were more likely to } \\
\text { have higher bedtime resistance, but higher } \\
\text { levels of HC may account for this } \\
\text { relationship; HC associated with bedtime } \\
\text { resistance significantly mediated the } \\
\text { relationship between Behavioural and } \\
\text { Emotional Screen System and bedtime } \\
\text { resistance. }\end{array}$ & \\
\hline Bridgett, 2013(40) & $\begin{array}{l}\text { HC mediated the effects of maternal self- } \\
\text { regulation on infant frustration/distress to } \\
\text { limitations. }\end{array}$ & \\
\hline Brieant, 2017(41) & & $\begin{array}{l}\text { Parent EF significantly predicted changes over time in adolescent EF, with } \\
\text { this association contingent on levels HC, such that a stronger relationship } \\
\text { was observed in the presence of greater HC. }\end{array}$ \\
\hline Chen, 2010(108) & $\begin{array}{l}\text { HC partially mediated the relationship } \\
\text { between SES and daily cortisol output. }\end{array}$ & \\
\hline Chen, 2014(46) & & $\begin{array}{l}\text { HC moderated the relationship between harsher maternal negativity and } \\
\text { child maladjustment in children who had low levels of effortful control. HC } \\
\text { did not moderate any other temperament-by-parenting interactions. }\end{array}$ \\
\hline Coldwell, 2006(4) & & $\begin{array}{l}\text { In a minority of cases, HC was found to moderate the role between } \\
\text { parenting and child behaviour, whereby HC exacerbated the effect of } \\
\text { poorer quality parenting on problem behaviour. }\end{array}$ \\
\hline $\begin{array}{l}\text { Deater-Deckard, } \\
\text { 2012(90) }\end{array}$ & & $\begin{array}{l}\text { Maternal EF moderated the relationship between child CP and harsh } \\
\text { parenting, so that this relationship was only significant in mothers with } \\
\text { poorer EF. Further, this moderating effect of EF was further moderated by } \\
\text { HC, so that the effect was particularly strong in the presence of low HC, } \\
\text { but not high HC. }\end{array}$ \\
\hline Evans, 2005(15) & $\begin{array}{l}\text { The adverse effects of poverty on } \\
\text { socioemotional adjustment were shown to } \\
\text { be mediated by HC. }\end{array}$ & \\
\hline $\begin{array}{l}\text { Farbiash, } \\
2014(47)\end{array}$ & $\begin{array}{l}\text { HC was found to significantly mediate the } \\
\text { relationship between paternal (but not } \\
\text { maternal) ADHD symptoms and children's } \\
\text { aggression in the preschool years. }\end{array}$ & \\
\hline Flouri, 2017(48) & HC did not mediate the relationship & \\
\hline
\end{tabular}




\begin{tabular}{|c|c|c|}
\hline & $\begin{array}{l}\text { between low SES and CP in children with } \\
\text { ADHD }\end{array}$ & \\
\hline $\begin{array}{l}\text { Fuller-Rowell, } \\
2015(51)\end{array}$ & & $\begin{array}{l}\text { Early HC moderated relationship between poverty and task persistence in } \\
\text { later adolescence. }\end{array}$ \\
\hline $\begin{array}{l}\text { Garrett-Peters, } \\
2016(27)\end{array}$ & $\begin{array}{l}\text { In the presence of household disorganisation } \\
\text { (but not instability), income poverty was no } \\
\text { longer directly related to academic } \\
\text { achievement. Income was related to } \\
\text { disorganisation, however, which in turn was } \\
\text { associated with lower academic } \\
\text { achievement. }\end{array}$ & \\
\hline Gould, 2017(52) & & $\begin{array}{l}\text { HC did not moderate the relationship between genes and development of } \\
\text { ADHD. }\end{array}$ \\
\hline Gregory, 2005(53) & $\begin{array}{l}\text { HC partially mediated the relationship } \\
\text { between sleep problems and child anxiety, } \\
\text { with HC accounting for } \sim 30 \% \text { of the } \\
\text { association. }\end{array}$ & \\
\hline Hart, 2007(11) & $\begin{array}{l}\text { HC mediated the relationship between } \\
\text { shared environmental variance and } \\
\text { longitudinal stability of cognitive ability in } \\
\text { early childhood. }\end{array}$ & \\
\hline Hur, 2015(29) & $\begin{array}{l}\text { HC mediated relationship between parental } \\
\text { depressive symptoms and mother-reported } \\
\text { social skills of child. }\end{array}$ & \\
\hline Kahn, 2016(59) & & $\begin{array}{l}\text { Hostile parenting mediated the relationship between parent and adolescent } \\
\mathrm{CU} \text {, but only in the presence of high HC. Harsh parenting explained } \\
\text { intergenerational similarity in CU traits, and HC exacerbated this } \\
\text { relationship. }\end{array}$ \\
\hline $\begin{array}{l}\text { Kim-Spoon, } \\
2017(60)\end{array}$ & & $\begin{array}{l}\text { High parental control predicted better neural cognitive control in } \\
\text { adolescents living in low HC contexts. Poor neural cognitive control was } \\
\text { associated with reduced social competence 1-year later (after controlling } \\
\text { for social competence at baseline), but this relationship was only } \\
\text { significant in high HC contexts. HC was shown to undermine positive } \\
\text { associations between parental control and adolescent neural cognitive } \\
\text { control and exacerbated the negative association between poor neural } \\
\text { cognitive control and social competence development. }\end{array}$ \\
\hline $\begin{array}{l}\text { Lauharatanahirun, } \\
\text { 2018(82) }\end{array}$ & & $\begin{array}{l}\text { HC moderated the relationship between adolescent-report of parental } \\
\text { knowledge/parental monitoring and adolescent insular risk processing, } \\
\text { which has been shown to precede risk-adverse choices, whereby it was } \\
\text { only present in the presence of low HC. }\end{array}$ \\
\hline $\begin{array}{l}\text { Lemery-Chalfant, } \\
\text { 2013(62) }\end{array}$ & & $\begin{array}{l}\text { Heritability of children's temperament was moderated by HC, meaning } \\
\text { that effortful control and surgency were more heritable in high HC } \\
\text { contexts. }\end{array}$ \\
\hline $\begin{array}{l}\text { Midouhas, } \\
\text { 2013(63) }\end{array}$ & & $\begin{array}{l}\text { Autism was associated with higher rates of psychopathology over time, and } \\
\text { family poverty was associated with emotional and CP (psychopathology); } \\
\text { however, home organisation did not moderate the relationship between } \\
\text { family poverty and psychopathology. }\end{array}$ \\
\hline $\begin{array}{l}\text { Mills-Koonce, } \\
\text { 2016(65) }\end{array}$ & & $\begin{array}{l}\text { HC did not moderate the relationship between parenting and child } \\
\text { behaviours. }\end{array}$ \\
\hline $\begin{array}{l}\text { Mokrova, } \\
\text { 2010(93) }\end{array}$ & $\begin{array}{l}\text { Mother's ADHD symptoms were positively } \\
\text { associated with inconsistent discipline and } \\
\text { non-supportive responses to child's negative } \\
\text { emotions; this relationship was mediated by }\end{array}$ & $\begin{array}{l}\text { Father's ADHD symptoms were associated with inconsistent discipline; this } \\
\text { relationship was moderated by HC. }\end{array}$ \\
\hline
\end{tabular}




\begin{tabular}{|c|c|c|}
\hline & $\begin{array}{l}\text { HC. Father's ADHD symptoms were } \\
\text { associated with low involvement; HC } \\
\text { mediated this relationship. }\end{array}$ & \\
\hline Oliver, 2008(66) & & $\begin{array}{l}\text { HC moderated the relationship between within-pair differences in } \\
\text { perceptions of the classroom environment and teacher report of less } \\
\text { prosocial and more hyperactive behaviour, and greater conduct and peer } \\
\text { problems. Specifically, associations between differential classroom } \\
\text { environment and CP were greater for children in more chaotic homes. }\end{array}$ \\
\hline Petrill, 2004(24) & $\begin{array}{l}\text { HC partially mediated an independent and } \\
\text { significant portion of the shared } \\
\text { environment for verbal and nonverbal and } \\
\text { PARCA scores at ages } 3 \text { and } 4 \text { years. HC } \\
\text { was a significant mediator even when } \\
\text { controlling for SES. }\end{array}$ & \\
\hline Shelleby, 2014(71) & $\begin{array}{l}\text { Significant direct association between } \\
\text { income and emotional problems and CP; HC } \\
\text { was a significant mediator in the } \\
\text { relationship between income and emotional } \\
\text { problems. }\end{array}$ & \\
\hline Taylor, 2014(36) & $\begin{array}{l}\text { HC mediated relationship between respect } \\
\text { for rules and increased reading } \\
\text { comprehension, even after controlling for } \\
\text { income. }\end{array}$ & \\
\hline $\begin{array}{l}\text { Towe-Goodman, } \\
2011(74)\end{array}$ & & $\begin{array}{l}\text { In a low-income sub-group, } \mathrm{HC} \text { was found to moderate the relationship } \\
\text { between interparental aggression in toddlerhood and the development of } \\
\text { child attention skills and early childhood behaviour problems at age } 3 \\
\text { years. In low-income families with low } \mathrm{HC} \text {, there was a significant } \\
\text { association between greater interparental aggression and increases 3-year } \\
\text { ADHD symptoms, but this relationship was not significant in low-income, } \\
\text { high HC families. }\end{array}$ \\
\hline Tucker, 2018(83) & & $\begin{array}{l}\text { HC moderated the effect of hostile parenting on adolescents' depression } \\
\text { two years later, so that depression was exacerbated in the context of high } \\
\text { HC. HC did not moderate the relationship between parenting and physical } \\
\text { health and problematic substance use. }\end{array}$ \\
\hline Wang, 2012(79) & & $\begin{array}{l}\text { HC moderated the genetic variance and covariance between externalising } \\
\text { problems and attention regulation, with the genetic influences stronger in } \\
\text { HC contexts; however, higher levels of HC attenuated the genetic } \\
\text { association between externalising problems and attention regulation. }\end{array}$ \\
\hline Wang, 2013(98) & & $\begin{array}{l}\text { The relationship between maternal attribution bias and parenting } \\
\text { behaviour were stronger in more chaotic environments; the moderating } \\
\text { effect of HC was particularly strong for internal attribution bias. }\end{array}$ \\
\hline $\begin{array}{l}\text { Wilkinson, } \\
2013(80)\end{array}$ & & $\begin{array}{l}\text { Depressive symptoms at age } 12 \text { were significantly heritable, and HC and } \\
\text { parenting style at age } 9 \text { years moderated this association. }\end{array}$ \\
\hline Wirth, 2017(100) & $\begin{array}{l}\text { The relationships between ADHD and } \\
\text { positive parenting, corporal punishment, and } \\
\text { inconsistent discipline were somewhat } \\
\text { mediated by HC. As such, high HC was } \\
\text { associated with specific parenting } \\
\text { dimensions in families with children with } \\
\text { ADHD. }\end{array}$ & \\
\hline
\end{tabular}

NSE $=$ Non-shared environment. 
Table 6: Mediation and moderation analysis of relationship between household chaos and outcome

Page $44 / 49$ 


\begin{tabular}{|c|c|c|}
\hline STUDY & RELATIONSHIP BETWEEN HC AND OUTCOME MEDIATED & $\begin{array}{l}\text { RELATIONSHIP BETWEEN HC AND } \\
\text { OUTCOME MODERATED }\end{array}$ \\
\hline $\begin{array}{l}\text { Asbury, } \\
2005(85)\end{array}$ & & $\begin{array}{l}\text { There was greater group heritability for verbal } \\
\text { ability, but not non-verbal ability, in early } \\
\text { childhood within the context of higher HC. }\end{array}$ \\
\hline $\begin{array}{l}\text { Berry, } \\
2016(26)\end{array}$ & & $\begin{array}{l}\text { Relationship between increased household } \\
\text { disorganisation and decreased cognitive and } \\
\text { social outcomes was somewhat moderated by } \\
\text { childcare hours (i.e. greater childcare hours } \\
\text { attenuated the relationship) }\end{array}$ \\
\hline $\begin{array}{l}\text { Brown, } \\
2008(43)\end{array}$ & $\begin{array}{l}\text { Sleep problems partially mediated the relationship between } \mathrm{HC} \text { and } \\
\text { hopeless/helpless responses to academic challenge. }\end{array}$ & \\
\hline $\begin{array}{l}\text { Corapci, } \\
2002(89)\end{array}$ & $\begin{array}{l}\text { Overall neither parental mood nor self-efficacy was found to mediate the } \\
\text { relationship between HC and parenting. }\end{array}$ & \\
\hline $\begin{array}{l}\text { Deater- } \\
\text { Deckard, } \\
2012(12)\end{array}$ & & $\begin{array}{l}\text { The relationship between } \mathrm{HC} \text { and maternal EF } \\
\text { was moderated by SES, meaning the adverse } \\
\text { effects of HC on maternal EF may be } \\
\text { particularly important within } \\
\text { socioeconomically distressed contexts. }\end{array}$ \\
\hline $\begin{array}{l}\text { Fisher, } \\
\text { 2018(81) }\end{array}$ & & $\begin{array}{l}\text { The quality of classroom climate across three } \\
\text { years of elementary school was not found to } \\
\text { moderate the relationship between HC and } \\
\text { adolescent outcomes. }\end{array}$ \\
\hline $\begin{array}{l}\text { Khatiwada, } \\
\text { 2018(118) }\end{array}$ & $\begin{array}{l}\text { HC was positively associated with weight status at } 12 \text { months of age; } \\
\text { however, this relationship was not mediated by breastfeeding, sleep, or } \\
\text { screen time. }\end{array}$ & \\
\hline $\begin{array}{l}\text { Kretschmer, } \\
2009(92)\end{array}$ & $\begin{array}{l}\text { The relationship between } \mathrm{HC} \text { and sibling relationship quality was mediated by } \\
\text { parenting, including maternal warmth and paternal harsh discipline. }\end{array}$ & $\begin{array}{l}\text { The relationship between } \mathrm{HC} \text { and sibling } \\
\text { relationship quality was moderated by maternal } \\
\text { harsh discipline. }\end{array}$ \\
\hline $\begin{array}{l}\text { Lemery- } \\
\text { Chalfant, } \\
2013(62)\end{array}$ & $\begin{array}{l}\text { Lower HC was associated with higher effortful control in children, and this } \\
\text { association was genetically mediated. }\end{array}$ & \\
\hline $\begin{array}{l}\text { Martin, } \\
2012(6)\end{array}$ & $\begin{array}{l}\text { Lack of routines was associated with lower receptive vocab and delayed } \\
\text { gratification. In homes with the TV usually on, children had greater } \\
\text { aggression scores and attention problems. The association between routines } \\
\text { and receptive vocab was partially mediated by provision of learning } \\
\text { materials. The association between lack of routines and delayed gratification } \\
\text { was not mediated by maternal warmth or provision of learning materials, } \\
\text { suggesting routines in and of themselves were associated with development of } \\
\text { early self-regulation. }\end{array}$ & \\
\hline $\begin{array}{l}\text { Miller, } \\
2017(64)\end{array}$ & & $\begin{array}{l}\text { HC was negatively associated with emotion } \\
\text { regulation, but this relationship was not } \\
\text { moderated by cortisol levels. The relationship } \\
\text { between routines and emotion regulation was } \\
\text { moderated by cortisol level, meaning that lack } \\
\text { of routines was more strongly associated with } \\
\text { poor emotion regulation in children with lower } \\
\text { cortisol output. }\end{array}$ \\
\hline $\begin{array}{l}\text { Mills- } \\
\text { Koonce, } \\
2016(65)\end{array}$ & $\begin{array}{l}\text { Maternal sensitivity and harsh parenting mediated the relationship between } \\
\text { HC and child behaviours. }\end{array}$ & \\
\hline $\begin{array}{l}\text { Supplee, } \\
2007(72)\end{array}$ & $\begin{array}{l}\text { Maternal report of HC was associated with children's externalising behaviour } \\
\text { at age } 4 \text { years, even after controlling for SES and ethnicity. }\end{array}$ & $\begin{array}{l}\text { HC was positively associated with teacher } \\
\text { report of externalising problems at school at }\end{array}$ \\
\hline
\end{tabular}

Page 45/49 


\begin{tabular}{|c|c|c|}
\hline & & $\begin{array}{l}\text { age } 5.5 \text { years. Maternal monitoring was not } \\
\text { found to moderate the effects of HC on } \\
\text { externalising behaviour. }\end{array}$ \\
\hline $\begin{array}{l}\text { Tucker, } \\
2015(75)\end{array}$ & & $\begin{array}{l}\text { HC predicted less positive adolescent beliefs } \\
\text { about mastery, future obstacles, and having a } \\
\text { successful career; mother's hostility moderated } \\
\text { the relationship between HC and future } \\
\text { obstacles and stress about the transition to } \\
\text { emerging adulthood. }\end{array}$ \\
\hline $\begin{array}{l}\text { Vernon- } \\
\text { Feagans, } \\
2012(86)\end{array}$ & $\begin{array}{l}\text { Household disorganisation was associated with variance in receptive and } \\
\text { expressive language; parenting partially mediated this relationship. }\end{array}$ & \\
\hline $\begin{array}{l}\text { Vernon- } \\
\text { Feagans, } \\
2016(77)\end{array}$ & $\begin{array}{l}\text { Disorganisation in the home was indirectly associated with behavioural } \\
\text { regulation through intermediate impacts on parenting behaviours and } \\
\text { children's early executive function skills. }\end{array}$ & \\
\hline $\begin{array}{l}\text { Zvara, } \\
2014(101)\end{array}$ & $\begin{array}{l}\text { Cumulative family disorganisation, but not cumulative family instability, was } \\
\text { found to have a significant indirect on children's representation of family } \\
\text { dysfunction through parenting behaviours. As such, the proximal effects of } \\
\text { daily disorganisation appeared to outweigh the effects of periodic instability } \\
\text { overtime. }\end{array}$ & \\
\hline
\end{tabular}

\section{Figures}




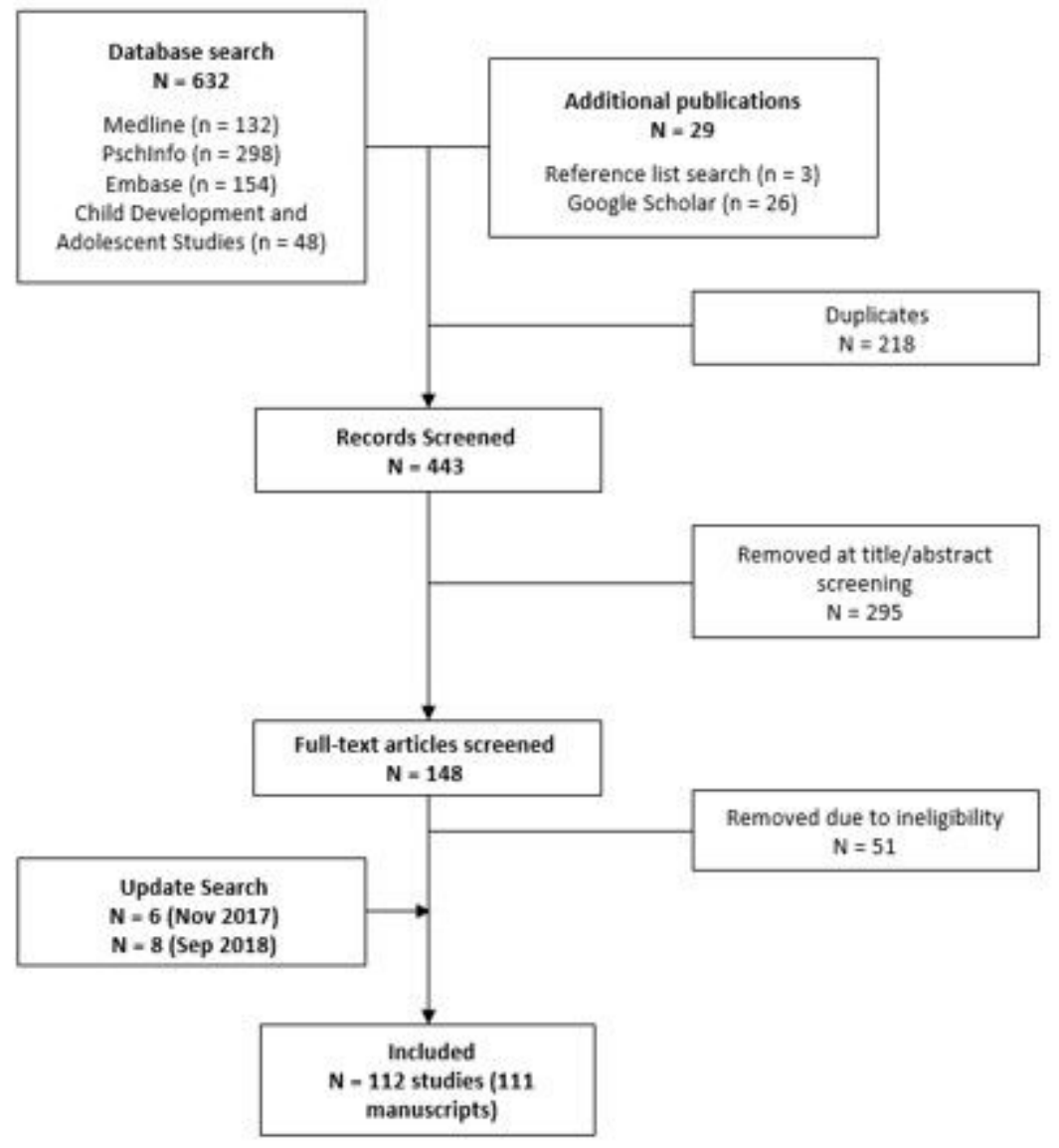

\section{Figure 1}

illustrates the different steps of the data collection process. 


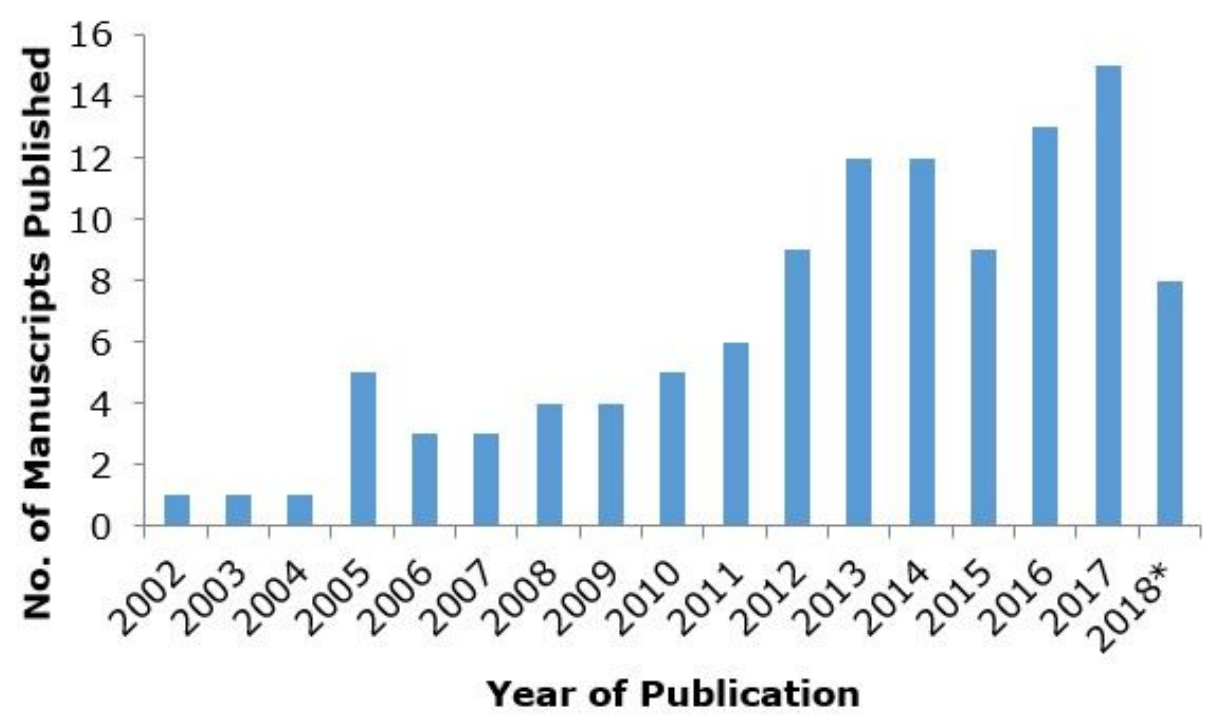

Figure 2

Number of household chaos publications by year

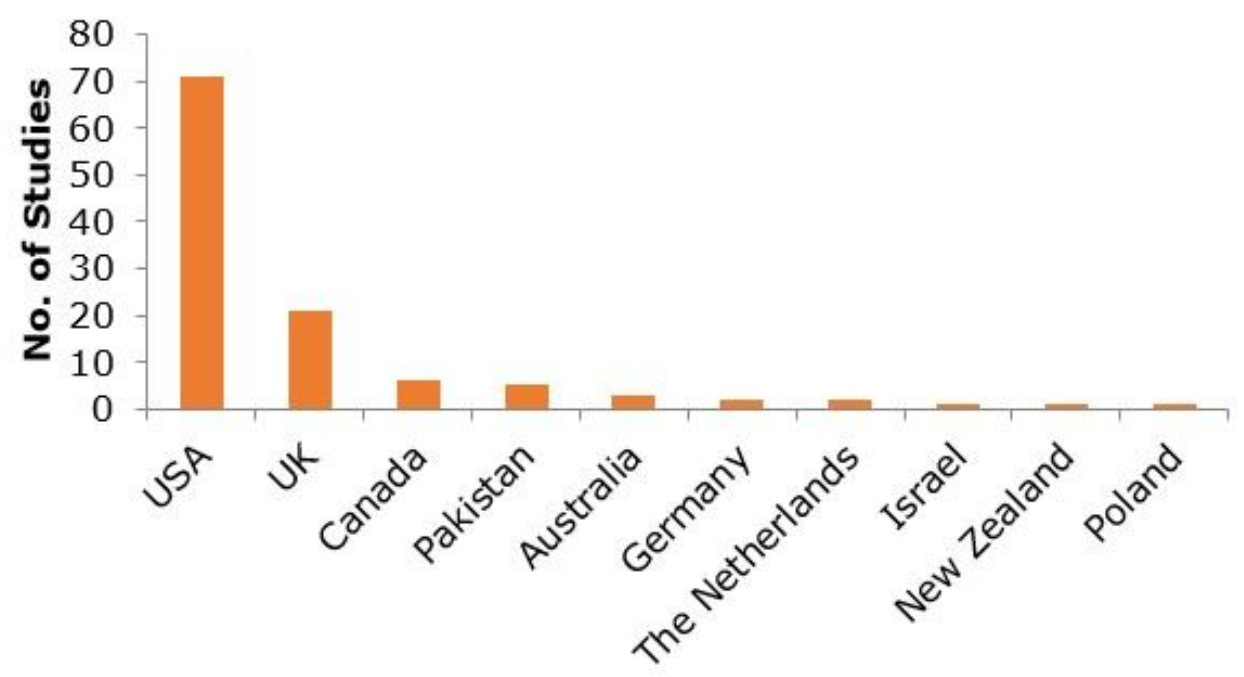

Study Location 
Figure 3

Number of published studies/analyses by country 